\title{
Chemical composition and bioavailability of thermally altered Pinus resinosa (Red pine) wood
}

\author{
Jeffrey A. Baldock ${ }^{\mathrm{a}, *}$, Ronald J. Smernik ${ }^{\mathrm{b}}$ \\ ${ }^{\mathrm{a} C S I R O}$ Land and Water, PMB 2, Glen Osmond, SA 5064, Australia \\ ${ }^{\mathrm{b}}$ Department of Soil and Water, University of Adelaide, PMB2, Glen Osmond, SA 5064, Australia
}

Received 2 January 2002; accepted 21 May 2002

(returned to author for revision 15 February 2002)

\begin{abstract}
The residues remaining after incomplete combustion of vegetation (char) can contribute significantly to the carbon content of soils. Char $\mathrm{C}$ is considered biologically inert relative to other forms of organic $\mathrm{C}$ in soils; however, the degree of biological inertness is likely to be a function of the extent that the combustion residues were altered during thermal treatment. The relationship between changes in chemical composition and biological inertness of char $\mathrm{C}$ created in the laboratory by heating Pinus resinosa sapwood to temperatures between 70 and $350{ }^{\circ} \mathrm{C}$ was quantified. Heating at each temperature was maintained until the mass of the residual char material stabilised $( \pm 2 \%)$. Chemical composition of the chars was assessed by elemental analysis, solid-state ${ }^{13} \mathrm{C}$ nuclear magnetic resonance (NMR) spectroscopy and diffuse reflectance infrared Fourier transform spectroscopy (DRIFT). The susceptibility of the heated sapwood to biological oxidation was quantified in a 120-day laboratory incubation. Thermal treatment at temperatures $\geqslant 200{ }^{\circ} \mathrm{C}$ induced significant variations in chemical composition. Changes in elemental contents and molar elemental ratios were consistent with an initial dehydration and the formation of unsaturated structures. The NMR and DRIFT data indicated that the changes in the chemical composition with increasing heating temperature included a conversion of O-alkyl C to aryl and O-aryl furan-like structures, consistent with results from work examining the chemical changes associated with thermal treatment of cellulose, the major component of wood. The chemical changes significantly reduced the ability of a microbial inoculum derived from decomposing Pinus resinosa wood to mineralise carbon contained in the charred samples. The $\mathrm{C}$ mineralisation rate constants decreased by an order of magnitude for wood heated to $\geqslant 200{ }^{\circ} \mathrm{C}$.
\end{abstract}

(C) 2002 Elsevier Science Ltd. All rights reserved.

\section{Introduction}

Interest in quantifying the amount of black carbon (BC) in terrestrial (soil) and aquatic (lacustrine and marine) environments has grown over the last decade given the potential implications that the presence of this material can have on biogeochemical processes. $\mathrm{BC}$ is terrestrial in origin and produced by the incomplete combustion of vegetation or fossil fuels (Goldberg,

\footnotetext{
* Corresponding author. Tel.: +61-8-83038537; fax: +61-883038550 .

E-mail address: jeff.baldock@adl.clw.csiro.au(J.A. Baldock).
}

1985). BC exists in a continuum of forms ranging from partially altered plant materials that survive combustion through to small submicron particles that form by the condensation of gaseous reaction products released during the combustion process (Schmidt and Noack, 2000; Glaser et al., 2001b). Many terms have been used to describe these products of combustion including char, charcoal, soot, graphitic carbon, and BC (Jones et al., 1997). In this study, the terms black carbon (BC), char and soot will be used to describe respectively the entire continuum of thermally altered organic matter, the thermally altered residue remaining after incomplete combustion of vegetation, and the products of gaseous condensation reactions. 
Char may contribute significantly to soil organic carbon (SOC) because of the ubiquitous occurrence of fire in most terrestrial environments. The presence of black carbon in the form of char or soot in soils has been demonstrated in numerous studies. Skjemstad et al. (1996) estimated that char carbon could account for up to $30 \%$ of the organic $\mathrm{C}$ in four Australian soils by application of a high-energy ultraviolet photooxidation $/{ }^{13} \mathrm{C}$ NMR procedure to various particle size fractions. Subsequent work with additional Australian soils and more rigorous ${ }^{13} \mathrm{C}$ NMR analyses (inclusion of a correction term to account for proton deficient char components) indicated that char $\mathrm{C}$ could account for $<1-57 \%$ of the SOC (Skjemstad et al., 1999a,b). Schmidt et al. (1999) estimated the contribution of char $\mathrm{C}$ to the SOC of nine German soils to range from 2 to $45 \%$ using the same analytical procedure as that of Skjemstad et al. (1996) and Skjemstad et al. (1999a). Using an analytical procedure based on the detection of benzene carboxylic acid markers, Glaser et al. (1998) estimated that char could account for between 0.8 and $24.3 \%$ of SOC in two German and two Brazilian soils. Subsequently, char was estimated to account for up to $35 \%$ of the black carbon contained in deep A horizons of 'Terra Preta' soils in the Amazon and up to $14 \%$ in the surface few centimetres of surrounding Oxisols (Glaser et al., 2001a). Based on gravimetric measurements of identifiable pieces of char, Saldarriaga and West (1986) estimated that char could account for 31-248 $\mathrm{Mg} \mathrm{C}^{-1}$ in the upper $50 \mathrm{~cm}$ of 'Terra Firme' soils in the upper Amazon basin.

The amount and composition of BC and char formed during biomass burning is controlled by a large number of variables related to the quantity, heterogeneity, and condition of combustible material present and the ambient environmental conditions (Van Wagner, 1980; Shafizadeh, 1984; Johnson, 1992; Bessie and Johnson, 1995). This leads to the formation of a product that varies in both composition and uniformity; however, one common feature of thermally altered materials is their high content of aryl $\mathrm{C}$ that increases with increasing extent of thermal alteration.

Char is generally considered to be biologically inert with long turnover times. Recent versions of most computer simulation models of SOC dynamics (e.g., Parton et al., 1987; Jenkinson et al., 1987) include an inert fraction of SOC that is thought to be dominated by the various forms of BC. It is probable, however, that the degree to which $\mathrm{BC}$ can be considered inert depends on the extent of alteration of the combustion residues. An ability of several wood-decaying fungi to decompose low grade coals (Scott et al., 1986; Hofrichter et al., 1999) suggests that micro-organisms present in soils may have the capacity to degrade char. However, radiocarbon ages of 1000-1500 years (Glaser, 1999) and the lack of an increase in $\mathrm{CO}_{2}$ release from an Andisol amended with char C (Shindo, 1991) over a 40 week incubation period under optimal conditions for microbial growth indicate that char may be recalcitrant in soils. Glaser et al. (2000) noted a potential biological stabilisation through an interaction with soil minerals after separating 'Terra Preta' soils on the basis of density. Although the highest amounts of char $\mathrm{C}$ were found in the light fraction $\left(<2.0 \mathrm{Mg} \mathrm{m}^{-3}\right)$ where no physical protection mechanism could account for recalcitrance, char $\mathrm{C}$ was also found partially surrounded by iron and aluminium oxide deposits on mineral surfaces in the medium $\left(2-2.4 \mathrm{Mg} \mathrm{m}^{-3}\right)$ and heavy $(>2.4 \mathrm{Mg}$ $\mathrm{m}^{-3}$ ) density fractions. In addition, the biological stability of char $\mathrm{C}$ is often inferred from its presence in geological sediments dating back to the Devonian period (Schmidt and Noack, 2000). However, as noted by Gélinas et al. (2001), the oxygen exposure time experienced by such particles is a key determinant of their longevity. Under conditions of rapid burial and incorporation into anoxic zones of sediments, little potential for oxidation would exist and the persistence of char for millennia may be more a function of its environment than its chemical composition.

In this study, the chemical changes associated with the formation of char from wood were characterised and the influence that these changes had on the biological availability (bioavailability) of wood carbon were quantified. The specific objectives were:

(1) to produce homogenous materials exemplifying an increasing extent of thermal alteration from red pine (Pinus resinosa) sapwood,

(2) to characterise the chemical structure of the thermally altered material using solid-state ${ }^{13} \mathrm{C}$ NMR spectroscopy, and

(3) to quantify the bioavailability of the thermally altered wood relative to that of unheated wood, cellulose and glucose, and define its relationship with chemical structure.

\section{Materials and methods}

\subsection{Collection and preparation of Pinus resinosa wood}

Five wooden disks, $10 \mathrm{~cm}$ in length and between 10 and $20 \mathrm{~cm}$ in diameter, were removed from the bole of ten Pinus resinosa trees on the same day as they were felled. The trees were located in a plantation near Chalk River, Ontario, Canada (Lat. 46.02 ${ }^{\circ} \mathrm{N}$, Long. $77.45^{\circ}$ $\mathrm{W})$. The wooden disks were returned to the laboratory dried to constant mass at $70{ }^{\circ} \mathrm{C}$ after which sapwood was separated from bark and heartwood. The sapwood was then ground to a particle size of $\leqslant 1 \mathrm{~mm}$ and thoroughly mixed to give one composite sample. 


\subsection{Preparation of the thermally altered wood}

Portions of the ground sapwood (30-100 g) were weighed into silica glass crucibles, spread evenly to a depth of $5 \mathrm{~mm}$, and heated to temperatures of 150, 200, 250,300 , and $350{ }^{\circ} \mathrm{C}$ in a muffle furnace. No attempt was made to prevent oxygen entry into the furnace; however, after closing the door the only point of entry for oxygen was the small hole in which a thermometer was placed. Heating continued (24-72 h) until the samples reached a constant mass $( \pm 2 \%)$. For each heating temperature, between three and five replicate portions of sapwood were used. At the end of the heating period, the altered wood from all replicates was combined to create one composite sample. The mass of sapwood, crucible size, and number of replicate portions prepared increased with increasing heating temperature in order to obtain a final composite sample of at least $50 \mathrm{~g}$ of thermally altered sapwood. A Campbell Scientific CR 12 data logger equipped with a thermocouple was used to record average hourly temperatures within the muffle furnace over the duration of the heating period. Temperature was found to deviate from that desired by $\pm 3{ }^{\circ} \mathrm{C}$.

\subsection{Mass loss and elemental contents of the thermally altered wood}

The mass loss from each replicate wood sample during heating was determined gravimetrically. The concentrations of $\mathrm{C}, \mathrm{N}$ and $\mathrm{H}$ in the initial dried sapwood (heated to $70{ }^{\circ} \mathrm{C}$ ) and the thermally altered composite wood samples were determined using a dry combustion CHN analyser (Carlo Erba Model 1106). The concentration of ash in each sample was determined gravimetrically after heating aliquots $(\sim 25 \mathrm{mg})$ of the samples to $650{ }^{\circ} \mathrm{C}$ for $18 \mathrm{~h}$ in a platinum boat (Nelson et al., 1995). Oxygen concentration was estimated by subtracting the sum of the $\mathrm{C}, \mathrm{N}$ and $\mathrm{H}$ concentrations from the ash free mass of wood. The significant effects of heating temperature on mass loss and elemental and ash concentrations were determined using a one-way ANOVA and a Tukey honest significant difference post hoc comparison with Statistica Version 6.0 (StatSoft, 2001).

\subsection{Chemical structure of unaltered and thermally altered wood}

Solid-state ${ }^{13} \mathrm{C}$ nuclear magnetic resonance (NMR) spectroscopy was used to characterise the chemistry of the unaltered and thermally altered wood. A Varian Unity 200 spectrometer operating at a ${ }^{13} \mathrm{C}$ frequency of $50.3 \mathrm{MHz}$ was used for all analyses. A measured mass of each wood (200-250 mg) was packed in a $7 \mathrm{~mm}$ diameter cylindrical zirconia rotor with Kel-F end-caps and spun at $5000 \pm 100 \mathrm{~Hz}$ in a Doty Scientific magic angle spinning (MAS) probe. Each free induction decay (FID) was acquired using a sweep width of $40 \mathrm{kHz}$. Over an acquisition time of $15 \mathrm{~ms}, 1216$ data points were collected. All spectra were zero filled to 8192 data points and processed with a $50 \mathrm{~Hz}$ Lorentzian line broadening and a $0.005 \mathrm{~s}$ Gaussian broadening. Chemical shifts were externally referenced to the methyl resonance of hexamethylbenzene at $17.36 \mathrm{ppm}$.

The unaltered and thermally altered woods were all characterised using a range of NMR analyses. A cross polarisation (CP) analysis was completed using a standard CP pulse sequence with a contact time of $1 \mathrm{~ms}$ and a recycle delay of $10 \mathrm{~s}$ (Wilson, 1987). Bloch decay (BD) analyses were completed using a $6.2 \mu$ s $\left(90^{\circ}\right){ }^{13} \mathrm{C}$ pulse with a $90 \mathrm{~s}$ recycle delay (Wilson, 1987). The long recycle delays of $10 \mathrm{~s}$ for $\mathrm{CP}$ analyses and of $90 \mathrm{~s}$ for $\mathrm{BD}$ analyses were used to avoid losses of signal intensity associated with saturation. Subsequent $\mathrm{T}_{1} \mathrm{H}$ analyses confirmed that the $10 \mathrm{~s}$ recycle delay used in the $\mathrm{CP}$ analyses was more than adequate and the high observabilities of carbon measured for the BD analyses suggest that the 90 s recycle delay was adequate. A total of 1000 transients were collected in the $\mathrm{CP}$ and $\mathrm{BD}$ analyses. Background corrections were not required for the $\mathrm{CP}$ analyses, but all BD analyses were corrected for background signals arising from the Kel-F end caps by subtraction of the FID acquired for an empty rotor assembly (Smernik and Oades, 2001).

The CP and corrected BD spectra were baseline corrected between -100 and 300 ppm after Fourier transformation of the acquired FID. The spectra were divided into the chemical shift regions identified in Table 1, and the signal intensity associated with each region determined by integration. The chemical shift limits selected and the inclusion of spectral regions with chemical shift limits $>215$ ppm were used to account for signal intensity in spinning side bands. Under the NMR conditions used in this study, spinning side bands were located approximately $100 \mathrm{ppm}$ on either side of their parent signals. To account for the intensity found in spinning side bands, the calculations presented in Table 1 were used. This procedure assumed that the two side bands associated with a given parent signal were of approximately equal intensity. The signal intensity present in each spectral region was then expressed as a percentage of the total signal intensity ( 300 to $-50 \mathrm{ppm})$.

Rates of proton spin-lattice relaxation in the static frame $\left(1 / \mathrm{T}_{1} \mathrm{H}\right)$ were determined using the methodology of Smernik et al. (2000). An inversion-recovery pulse sequence utilizing 10-13 recovery delays varying between 0.0001 and $5 \mathrm{~s}$, a $1 \mathrm{~ms}$ contact time, and a $10 \mathrm{~s}$ recycle delay was used. For each recovery delay, 400 transients were collected.

Rates of proton spin-lattice relaxation in the rotating frame $\left(1 / \mathrm{T}_{1} \rho \mathrm{H}\right)$ were determined using a variable spin 
lock (VSL) pulse sequence (Alla and Lippmaa, 1976). The spin lock times used were $0,0.5,1,1.5,2,3,4,5,7$ and $9 \mathrm{~ms}$, and in each case the spin lock was followed by a $1 \mathrm{~ms}$ contact time. The recycle delays used in the VSL experiments were $1.0 \mathrm{~s}$ for the 70,150 and $200{ }^{\circ} \mathrm{C}$ heated wood samples and $0.5 \mathrm{~s}$ for the 250,300 and $350{ }^{\circ} \mathrm{C}$ heated wood samples. A total of 3000-5000 transients were accumulated per spin lock delay for each VSL experiment. Values of $\mathrm{T}_{1} \rho \mathrm{H}$ were calculated as the inverse slope $(1 / \mathrm{m})$ of the graph of $\ln$ (total signal intensity) versus variable spin lock time.

The proportion of organic $\mathrm{C}$ in the wood samples that was NMR observable $\left(\mathrm{C}_{\text {obs }}\right)$ was assessed for the $\mathrm{CP}$ and BD analyses using the methodology of Smernik and Oades (2000a,b). Glycine was used as an external intensity standard (i.e. the glycine spectra were acquired separately to those of the thermally treated wood samples). $\mathrm{CP}-\mathrm{C}_{\mathrm{obs}}$ and $\mathrm{BD}-\mathrm{C}_{\mathrm{obs}}$ values were determined according to Eqs. (1) and (2). The determination of CP$\mathrm{C}_{\mathrm{obs}}$ requires a correction for signal due to $\mathrm{T}_{1} \rho \mathrm{H}$ relaxation during the contact time (Smernik and Oades, 2000a).

$$
\begin{array}{r}
\mathrm{CP}-\mathrm{C}_{\mathrm{obs}}=\left(\frac{\text { Sample } \mathrm{T}_{1} \rho \mathrm{H} \text { corrected signal intensity }}{\text { Mass of sample } \mathrm{C} \text { analysed }(\mathrm{mg})}\right) \\
\left(\frac{\text { Glycine } \mathrm{T}_{1} \rho \mathrm{H} \text { corrected signal intensity }}{\text { Mass of glycine } \mathrm{C} \text { analysed }(\mathrm{mg})}\right)^{-1}
\end{array}
$$

$$
\begin{aligned}
\text { BD- } \mathrm{C}_{\mathrm{obs}}= & \left(\frac{\text { Sample BD signal intensity }}{\text { Mass of sample } \mathrm{C} \text { analysed }(\mathrm{mg})}\right) \\
& \left(\frac{\text { Glycine BD signal intensity }}{\text { Mass of glycine } \mathrm{C} \text { analysed }(\mathrm{mg})}\right)^{-1}
\end{aligned}
$$

DRIFT spectra of all samples were acquired with a rapid-scan Bio-Rad FTS-175 FTIR spectrometer equipped with a Peltier-cooled DTGS detector and extended range $\mathrm{KBr}$ beam-splitter. Samples were scanned 50 times with an $8 \mathrm{~cm}^{-1}$ resolution and a $0.5 \mathrm{~s}$ scan rate to give a spectrum range of $8000-470 \mathrm{~cm}^{-1}$. Sampling was by diffuse reflectance from a neat powdered sample surface using an off-axis diffuse reflectance accessory (HarrickTM DRS-3SO). The instrument compartment and sample chamber were purged with $\mathrm{H}_{2} \mathrm{O}$ - and $\mathrm{CO}_{2}$-free air to remove atmospheric absorption bands. WIN_IR Ver. 4.0, a variant of the Galactic (NH) GRAMS-32 operating system, was provided as the standard operating system for the FTS-175 spectrometer.

\subsection{Bioavailability of unaltered and thermally altered wood}

The bioavailability of the unaltered and thermally altered sapwood samples was compared to that of glucose and cellulose and assessed by determining the proportion of the added organic carbon that remained after a 120 day laboratory incubation. In the incubation, water, nutrients and a microbial inoculum were added to sand amended with equivalent amounts of organic carbon derived from glucose, cellulose, unaltered wood, or the thermally altered woods. The sand was used to provide a support matrix that held an adequate amount of water, but also provided adequate aeration. Nutrients and a microbial inoculum were added to the sand/ organic mixture and the mixture was incubated at $25^{\circ} \mathrm{C}$, to create an environment conducive to enhanced decomposition rates. The objective of the work was not to determine absolute decomposition rates indicative of

Table 1

Chemical shift regions into which the acquired total ${ }^{13} \mathrm{C}$ NMR signal intensity was divided, the proposed major types of carbon from which the intensity in each region was derived, and the calculations used to determine the amount of total signal intensity associated with each chemical shift region

\begin{tabular}{lll}
\hline $\begin{array}{l}\text { Chemical shift } \\
\text { limits (ppm) }\end{array}$ & Proposed dominant type of C & $\begin{array}{l}\text { Calculations used to quantify the } \\
\text { amount of signal intensity associated } \\
\text { with each type of carbon }\end{array}$ \\
\hline $290-265$ & Carbonyl and amide spinning side band & \\
$265-245$ & O-Aryl spinning side band & \\
$245-215$ & Aryl spinning side band & $(215-190 \mathrm{ppm})$ \\
$215-190$ & Ketone C & $(190-165 \mathrm{ppm})+2 \times(290-265 \mathrm{ppm})$ \\
$190-165$ & Carbonyl and amide C & $(165-145 \mathrm{ppm})+2 \times(265-245 \mathrm{ppm})$ \\
$165-145$ & O-Aryl C (phenolic and furan $)$ & $(145-110 \mathrm{ppm})+2 \times(245-215 \mathrm{ppm})$ \\
$145-110$ & Aryl and unsaturated C & $(110-90 \mathrm{ppm})$ \\
$110-90$ & Di-O-Alkyl C & $(90-65 \mathrm{ppm})-(290-265 \mathrm{ppm})$ \\
$90-65$ & O-Alkyl C & $(65-45 \mathrm{ppm})-(265-245 \mathrm{ppm})$ \\
$65-45$ & Methoxyl and N-alkyl C & $(0-45 \mathrm{ppm})-(215-245 \mathrm{ppm})$ \\
$45-0$ & Alkyl C &
\end{tabular}


those that occur naturally, but rather to define the relative bioavailability of the organic $\mathrm{C}$ contained in glucose, cellulose and natural and thermally altered Pinus resinosa sapwood.

The sand used in this study was heated to $500{ }^{\circ} \mathrm{C}$ for $48 \mathrm{~h}$ in a muffle furnace to remove any organic materials. After heating, the sand had a $\mathrm{pH}$ of 4.1 in a 1:5 soil:water suspension. Calcium carbonate was added to the sand $\left(2.9 \mathrm{~g} \mathrm{CaCO}_{3} \mathrm{~kg}^{-1}\right.$ sand) to increase its $\mathrm{pH}$ to 6.3. The calcium carbonate amended sand will be referred to subsequently as the sand medium.

The sand medium was packed to a bulk density of 1.6 $\mathrm{Mg} \mathrm{m}^{-3}$ and its water holding capacity and water retention characteristic were determined. After allowing a $5 \mathrm{~cm}$ height of sand medium to drain freely from saturation, the volumetric water holding capacity of the sand was $0.29 \mathrm{~cm}^{3} \mathrm{~cm}^{-3}$ which corresponded to a water filled porosity of $0.75 \mathrm{~cm}^{3}$ water $\mathrm{cm}^{-3}$ pore space. The water retention characteristic, determined using a pressure plate apparatus, indicated that the matric potential of water in the sand medium at a volumetric water content of $0.29 \mathrm{~cm}^{3} \mathrm{~cm}^{-3}$ was approximately $2.7 \mathrm{kPa}$. At a matric potential of $10 \mathrm{kPa}$, the water content decreased to $0.03 \mathrm{~cm}^{3} \mathrm{~cm}^{-3}$. All incubations were conducted using a volumetric water content of $0.29 \mathrm{~cm}^{3}$ water $\mathrm{cm}^{-3}$ soil.

A microbial inoculum was isolated from the sapwood of a decomposing Pinus resinosa log located in the plantation where the original wood samples were collected. The decomposing sapwood had lost most of its structural integrity and was easily pulled apart by hand. The decomposed sapwood was incubated at $25^{\circ} \mathrm{C}$ for 16 days in the absence of light to enhance the activity and population of decomposer microorganisms present. The initial gravimetric water content of the wood $(2.77 \mathrm{~g}$ water $\mathrm{g}^{-1}$ wood) was maintained throughout the 16 days and the microbial inoculum was isolated by adding $25 \mathrm{~g}$ equivalent dry mass of the wet-incubated-decomposed wood to 11 of sterile deionised/distilled water filtered to $<0.45 \mu \mathrm{m}$, shaking for $2 \mathrm{~h}$, filtering through a 1 $\mathrm{mm}$ sieve, and centrifuging the filtrate at $2000 \mathrm{rpm}$ for 5 $\min$. The isolation procedure was repeated and the two supernatants were mixed to produce a single microbial inoculum.

A nutrient solution was prepared by adding $10.324 \mathrm{~g}$ $\mathrm{NH}_{4} \mathrm{NO}_{3}, 0.272 \mathrm{~g} \mathrm{CaSO}_{4}, 0.493 \mathrm{~g} \mathrm{MgSO}_{4} 7 \mathrm{H}_{2} \mathrm{O}, 1.361 \mathrm{~g}$ $\mathrm{CaH}_{2} \mathrm{PO}_{4}, 0.436 \mathrm{~g} \mathrm{~K}_{2} \mathrm{SO}_{4}$, and $1 \mathrm{ml}$ of a micronutrient solution (Hellgren and Ingestad, 1996) to a 11 volumetric flask. The microbial inoculum was then used to bring the solution up to a volume of 11 to produce a nutrient/inoculum solution.

A measured mass of each organic amendment was mixed with $250 \mathrm{~g}$ of the sand media in a dry state to prepare a bulk sample with a known organic carbon content of approximately $10 \mathrm{~g}$ organic $\mathrm{C} \mathrm{kg}^{-1}$ sample. To each dry bulk sample, $46.1 \mathrm{~g}$ of the nutrient/inoculum solution was added and thoroughly mixed in. The quantity of nutrient/inoculum solution used produced a bulk sample with a volumetric water content of $0.29 \mathrm{~cm}^{3}$ $\mathrm{cm}^{-3}$ when packed to a bulk density of $1.6 \mathrm{Mg} \mathrm{m}^{-3}$, and the concentration of nitrogen used gave an organic $\mathrm{C}$ : total $\mathrm{N}$ mass ratio of 15 in the samples. A measured mass of the moist bulk sample (approximately $25 \mathrm{~g}$ dry mass) was placed into an $80 \mathrm{~cm}^{3}$ plastic container and packed to a bulk density of $1.6 \mathrm{Mg} \mathrm{m}^{-3}$. The containers were then placed into 11 glass jars and $5 \mathrm{~cm}^{3}$ of deionised/distilled water was added to the bottom of the jars and air tight lids were fitted. The incubation samples were placed in a controlled environment chamber at $25^{\circ} \mathrm{C}$ and incubated for 120 days in the absence of light. During the 120 day incubation period, the jars were opened periodically to ensure adequate oxygen concentration within the jars. The incubation samples were weighed every 20 days and additional deionised/distilled water was added when required to maintain the desired water content.

The organic carbon content of the bulk samples and that of the incubation samples after 120 days incubation were determined using a dry combustion LECO CR-12 carbon analyser. The relative biological availability of the organic carbon contained in each treatment was assessed by determining the fraction of the initial organic $\mathrm{C}$ that was respired during the 120 day incubation.

A total of six replicate incubation samples were prepared for each of the following eight treatments.

(1) Glucose - sand media, nutrient/inoculum solution, glucose.

(2) Cellulose - sand media, nutrient/inoculum solution, cellulose.

(3) $70{ }^{\circ} \mathrm{C}$ wood-sand media, nutrient/inoculum solution, unaltered wood (heated to $70{ }^{\circ} \mathrm{C}$ ).

(4) $150{ }^{\circ} \mathrm{C}$ wood—sand media, nutrient/inoculum solution, wood thermally altered at $150{ }^{\circ} \mathrm{C}$.

(5) $200{ }^{\circ} \mathrm{C}$ wood-sand media, nutrient/inoculum solution, wood thermally altered at $200{ }^{\circ} \mathrm{C}$.

(6) $250{ }^{\circ} \mathrm{C}$ wood - sand media, nutrient/inoculum solution, wood thermally altered at $250{ }^{\circ} \mathrm{C}$.

(7) $300{ }^{\circ} \mathrm{C}$ wood - sand media, nutrient/inoculum solution, wood thermally altered at $300{ }^{\circ} \mathrm{C}$.

(8) $350{ }^{\circ} \mathrm{C}$ wood-sand media, nutrient/inoculum solution, wood thermally altered at $350^{\circ} \mathrm{C}$.

The replicates of each treatment were arranged randomly within the controlled environment chamber and the placement of each incubation vessel was altered each time the vessels were opened. An ANOVA utilising a complete randomised design was used to identify significant treatment effects. A Tukey's honest significant difference test was used to determine which treatment means were significantly different from one another. Statistical analyses were completed using Statistica Version 6.0 (StatSoft, 2001). 


\section{Results and discussion}

\subsection{Mass loss, elemental concentrations and molar elemental ratios}

As the heating temperature increased from 150 to $300{ }^{\circ} \mathrm{C}$, the fraction of Pinus resinosa sapwood lost on heating to constant mass increased from 3 to $81 \%$ (Table 2). A further increase in heating temperature to $350{ }^{\circ} \mathrm{C}$ did not result in a significant increase in mass loss above that noted for the $300{ }^{\circ} \mathrm{C}$ treatment. After heating to $400{ }^{\circ} \mathrm{C}$, no measurable organic carbon remained and this temperature treatment was excluded from the study. Mass losses of a similar magnitude have been observed in studies where natural organic materials were either exposed to increasing temperatures for a constant duration or to a constant elevated temperature for an increasing duration. Mass losses increased from 37 to $93 \%$ on exposure of cellulose, the major component of wood, to temperatures of $325-500{ }^{\circ} \mathrm{C}$ for $5 \mathrm{~min}$ (Shafizadeh, 1984). Shafizadeh (1984) also reported losses of 75 and $27 \%$, respectively, when wood and lignin were heated to $400{ }^{\circ} \mathrm{C}$ for $5 \mathrm{~min}$. Glaser et al. (1998) observed mass losses of $12-78 \%$ on heating Pinus sylvestris wood to $300{ }^{\circ} \mathrm{C}$ for durations between 0.25 and $10 \mathrm{~h}$. Mass losses of 30-60\% were reported by Torn et al. (1997) on heating ryegrass shoot material to $350{ }^{\circ} \mathrm{C}$ for periods of 30-90 s and Almendros et al. (1990) noted losses of $10-64 \%$ on heating soil humic and fulvic acids to $350{ }^{\circ} \mathrm{C}$ for durations of $60-150 \mathrm{~s}$.

Changes in the elemental concentrations of $\mathrm{C}, \mathrm{H}, \mathrm{O}$ and $\mathrm{N}$ in the sapwood were observed with increasing heating temperature (Table 2). Heating to $150{ }^{\circ} \mathrm{C}$ did not alter organic $\mathrm{C}$ or $\mathrm{N}$ concentration; however, at temperatures $>150{ }^{\circ} \mathrm{C}$, the $\mathrm{C}$ and $\mathrm{N}$ concentrations of the residual material increased and attained values of
$673 \mathrm{~g} \mathrm{C} \mathrm{kg}^{-1}$ and $2.50 \mathrm{~g} \mathrm{~N} \mathrm{~kg}^{-1}$, respectively, after heating to $350{ }^{\circ} \mathrm{C}$. The concentration of $\mathrm{C}$ increased progressively with increasing heating temperature; whilst, $\mathrm{N}$ concentration was greatest for sapwood heated to $300{ }^{\circ} \mathrm{C}$ and then decreased on further heating to $350{ }^{\circ} \mathrm{C}$. Conversely, concentrations of $\mathrm{H}$ and $\mathrm{O}$ tended to decrease with increasing heating temperature. The $\mathrm{O}$ concentration was not affected by heating to $150{ }^{\circ} \mathrm{C}$, but progressively decreased with further increases in heating temperature to $286 \mathrm{~g} \mathrm{O} \mathrm{kg}^{-1}$ after heating to $350{ }^{\circ} \mathrm{C}$. H concentration did not change on heating to temperatures $\leqslant 150{ }^{\circ} \mathrm{C}$ and then decreased as heating temperature increased to $250{ }^{\circ} \mathrm{C}$. The $\mathrm{H}$ concentration after heating to $300{ }^{\circ} \mathrm{C}$ was not different from that after $250{ }^{\circ} \mathrm{C}$; however, an increase in $\mathrm{H}$ concentration was noted after further heating to $350{ }^{\circ} \mathrm{C}$.

The changes in elemental concentrations observed with increasing extent of thermal alteration were consistent with those measured previously by Shafizadeh (1984) for cellulose, wood and lignin, Shindo (1991) for grass, Glaser et al. (1998) for Pinus sylvestris wood, and Almendros et al. (1990) for soil humic and fulvic acids. Contrary to these results, Knicker et al. (1996) noted decreasing $\mathrm{C}, \mathrm{H}$ and $\mathrm{N}$ concentrations with increasing duration of heating of ryegrass at $350{ }^{\circ} \mathrm{C}$; however, their results were not corrected for ash contents. Although the general trends in elemental composition were consistent, the magnitude of the changes observed varied. Such variations are suspected to be a function of the differences in heating methods used (temperature and exposure duration) and in particular the degree to which $\mathrm{O} 2$ was excluded from the samples during heating.

Molar elemental ratios of the sapwood were also influenced by heating temperatures $>150^{\circ} \mathrm{C}$ (Table 3 ). In progressing from a heating temperature of 150

Table 2

Mass loss associated with the heating of Pinus resinosa sapwood to the indicated temperatures and gravimetric elemental concentrations and ash content of the heated sapwood. Values in parentheses are the standard deviations of the means

\begin{tabular}{|c|c|c|c|c|c|c|}
\hline \multirow{2}{*}{$\begin{array}{l}\text { Heating } \\
\text { temperature } \\
\left({ }^{\circ} \mathrm{C}\right)\end{array}$} & \multirow{2}{*}{$\begin{array}{l}\text { Mass loss } \\
\text { (\% initial mass) } \\
n=3-5\end{array}$} & \multicolumn{4}{|c|}{ Elemental concentrations $\left(\mathrm{g} \mathrm{kg}^{-1}\right) n=3$} & \multirow{2}{*}{$\begin{array}{l}\text { Ash content } \\
\left(\mathrm{g} \mathrm{kg}^{-1}\right) \\
n=1\end{array}$} \\
\hline & & $\mathrm{C}$ & $\mathrm{H}$ & $\mathrm{N}$ & $\mathrm{O}$ & \\
\hline 70 & 0 & $479^{\mathrm{e}}(2)$ & $60.7^{\mathrm{a}}(0.7)$ & $0.80^{\mathrm{e}}(0.04)$ & $458^{\mathrm{a}}(2)$ & 2 \\
\hline 150 & $3.2^{\mathrm{a}}(0.3)$ & $484^{e}(5)$ & $58.6^{\mathrm{a}}(1.8)$ & $0.83^{\mathrm{e}}(0.03)$ & $453^{a}(6)$ & 3 \\
\hline 200 & $35.0^{\mathrm{b}}(1.0)$ & $525^{\mathrm{d}}(1)$ & $44.4^{\mathrm{d}}(1.1)$ & $1.05^{\mathrm{d}}(0.04)$ & $426^{\mathrm{b}}(2)$ & 3 \\
\hline 250 & $61.6^{\mathrm{c}}(2.9)$ & $610^{\mathrm{c}}(3)$ & $25.7^{\mathrm{d}}(1.3)$ & $1.65^{\mathrm{c}}(0.01)$ & $358^{\mathrm{c}}(4)$ & 5 \\
\hline 300 & $81.4^{\mathrm{d}}(3.0)$ & $628^{\mathrm{b}}(1)$ & $23.8^{\mathrm{d}}(1.0)$ & $2.93^{\mathrm{a}}(0.03)$ & $339^{\mathrm{d}}(1)$ & 7 \\
\hline 350 & $86.7^{\mathrm{d}}(2.5)$ & $673^{a}(4)$ & $30.4^{\mathrm{c}}(2.1)$ & $2.50^{\mathrm{b}}(0.07)$ & $286^{\mathrm{e}}(6)$ & 8 \\
\hline ANOVA $P$-value & $<0.0001$ & $<0.0001$ & $<0.0001$ & $<0.0001$ & $<0.0001$ & \\
\hline
\end{tabular}

The number of replicate determinations used to calculate the mean and standard deviation is given by $n$. Mean mass loss, elemental concentrations and ash contents with different superscript letters were significantly different at $\alpha=0.05$ as identified using a one-way ANOVA and a Tukey's honest significant difference post-hoc comparison (Statsoft, 2001). 
$300{ }^{\circ} \mathrm{C}$, the $\mathrm{H} / \mathrm{C}, \mathrm{O} / \mathrm{C}$ and $\mathrm{H} / \mathrm{O}$ ratios all decreased and the $\mathrm{N} / \mathrm{C}$ ratio increased. Relative to carbon, the changes in elemental ratios indicated a progressive loss of $\mathrm{H}$ and $\mathrm{O}$, with the loss of $\mathrm{H}$ being approximately twice that of $\mathrm{O}$, and an accumulation of $\mathrm{N}$ in the residues remaining after heating. The progressive decrease in $\mathrm{H} / \mathrm{C}$ ratio was indicative of the formation of structures containing unsaturated carbons such as aromatic rings and was consistent with the aromatisation of cellulose observed with increasing extent of thermal alteration (Shafizadeh, 1984; Pastorova et al., 1994). With further heating to $350{ }^{\circ} \mathrm{C}$, the $\mathrm{O} / \mathrm{C}$ ratio continued to decrease, the $\mathrm{H} / \mathrm{C}$ and $\mathrm{H} / \mathrm{O}$ ratios increased, and the $\mathrm{N} / \mathrm{C}$ ratio decreased. The variation in the direction of change for the $\mathrm{H} / \mathrm{C}$, $\mathrm{H} / \mathrm{O}$, and $\mathrm{N} / \mathrm{C}$ ratios indicated that the nature of the material lost on heating to $350^{\circ} \mathrm{C}$ differed from that lost at lower heating temperatures. Although the $\mathrm{O} / \mathrm{C}$ ratio decreased with increasing extent of thermal alteration, even after heating to $350{ }^{\circ} \mathrm{C}$, the residual structures contained an average of one $\mathrm{O}$ atom for every three $\mathrm{C}$ atoms. Such a concentration of $\mathrm{O}$ within the residue is not consistent with the large highly condensed aromatic structures commonly proposed for soot and charred organic materials (e.g. Schmidt and Noack, 2000). A smaller average molecular size and an incorporation of $\mathrm{O}$ into ring structures such as furan or furan-like structures or the presence of phenolic, carbonyl or carboxyl groups would help to explain this result.

Presentation of molar elemental data in the form of $\mathrm{H} / \mathrm{C}$ and $\mathrm{O} / \mathrm{C}$ molar ratios in a Van Krevelen plot (1950) (Fig. 1) provides information pertaining to the extent of alteration induced by various heating procedures, the nature of the reactions that take place during the heating process, and the similarities and differences between chars produced from different starting materials or using different methods of heating. All samples of unheated wood should fall within the compositional space defined by plotting the $\mathrm{H} / \mathrm{C}$ versus $\mathrm{O} / \mathrm{C}$ molar ratios for pure carbohydrate, lignin, lipid and protein (the major components of wood). This region is defined by the grey triangle in Fig. 1a. The theoretical $\mathrm{H} / \mathrm{C}$ and $\mathrm{O} / \mathrm{C}$ ratios for the carbohydrate component were calculated from the distribution of hexose and pentose monomers present in a 5:2 mixture of cellulose $(100 \%$ hexose) and hemicellulose (25\% hexose and $75 \%$ pentose) after subtraction of one water molecule for each monomeric species to account for polymerisation. For lignin, the ratios were calculated from the theoretical structures of pure guaiacyl or syringyl monomers joined together by $\beta-O-4$ linkages (Baldock and Preston, 1995). The ratios for the lipid component were calculated using linoleic acid based on the observation that the lipid fraction of Pinus sylvestris wood was dominated by 18:1, 18:2 and 18:3 fatty acids (Saranpää and Nyberg, 1987). The $18: 2$ fatty acid accounted for $41 \%$ of the total fatty acids, whilst the $18: 1$ and $18: 3$ fatty acids each accounted for approximately $23 \%$, suggesting that, on average, the lipid fraction could be represented by linoleic acid, an 18:2 fatty acid. The theoretical ratios for protein were derived from amino acid distributions measured in wood collected from fertilised Pinus sylvestris trees (Nordin et al., 2001). The unheated Pinus resinosa sapwood used in this study and the unheated wood used by Shafizadeh (1984) fall within the bounds of possible wood composition, close to the theoretical composition of carbohydrate and the line linking carbohydrate to lignin. The placement of these woods within the possible compositional space is consistent with the dominance of cellulose/hemicellulose and lignin polymers in wood.

The positioning on a Van Krevelen plot of the heated samples produced in this study and various other thermally altered organic materials is shown in Fig. $1 \mathrm{~b}$ and 1c. Data collected in this study were consistent with those collected previously, and indicated a progression towards graphitic like materials with increasing heating temperature or duration (i.e. increased extent of thermal alteration). The dehydration and oxidation arrows in

Table 3

Molar elemental ratios calculated for Pinus resinosa sapwood heated to the indicated temperatures

\begin{tabular}{|c|c|c|c|c|}
\hline \multirow[t]{2}{*}{ Heating temperature $\left({ }^{\circ} \mathrm{C}\right)$} & \multicolumn{4}{|c|}{ Molar elemental ratios $(n=3)$} \\
\hline & $\mathrm{H} / \mathrm{C}$ & $\mathrm{O} / \mathrm{C}$ & $\mathrm{N} / \mathrm{C}$ & $\mathrm{H} / \mathrm{O}$ \\
\hline 70 & $1.52^{\mathrm{a}}(0.02)$ & $0.72^{\mathrm{a}}(0.01)$ & $0.00143^{\mathrm{e}}(0.00008)$ & $2.12^{\mathrm{a}}(0.03)$ \\
\hline 150 & $1.45^{\mathrm{a}}(0.03)$ & $0.70^{\mathrm{a}}(0.02)$ & $0.00147^{\mathrm{e}}(0.00006)$ & $2.07^{\mathrm{a}}(0.09)$ \\
\hline 200 & $1.02^{\mathrm{b}}(0.02)$ & $0.61^{\mathrm{b}}(0.00)$ & $0.00171^{\mathrm{d}}(0.00007)$ & $1.67^{b}(0.05)$ \\
\hline 250 & $0.51^{\mathrm{cd}}(0.03)$ & $0.44^{\mathrm{c}}(0.01)$ & $0.00231^{\mathrm{c}}(0.00001)$ & $1.15^{\mathrm{c}}(0.07)$ \\
\hline 300 & $0.46^{\mathrm{d}}(0.02)$ & $0.40^{\mathrm{d}}(0.00)$ & $0.00400^{\mathrm{a}}(0.00003)$ & $1.12^{\mathrm{c}}(0.05)$ \\
\hline 350 & $0.54^{\mathrm{c}}(0.03)$ & $0.32^{\mathrm{e}}(0.01)$ & $0.00319^{\mathrm{b}}(0.00007)$ & $1.70^{\mathrm{b}}(0.15)$ \\
\hline ANOVA $P$-value & $<0.0001$ & $<0.0001$ & $<0.0001$ & $<0.0001$ \\
\hline
\end{tabular}

Values in parentheses are the standard deviation of the means. The number of replicate determinations used to calculate the mean and standard deviation is given by $n$. Ratios with different superscript letters were significantly different at $\alpha=0.05$ as identified using a one-way ANOVA and a Tukey's honest significant difference post-hoc comparison (StatSoft, 2001). 


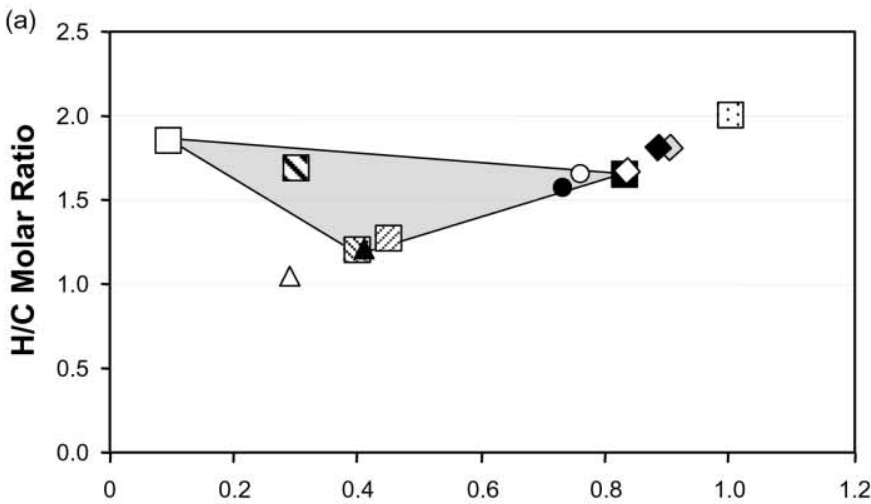

O/C Molar Ratio

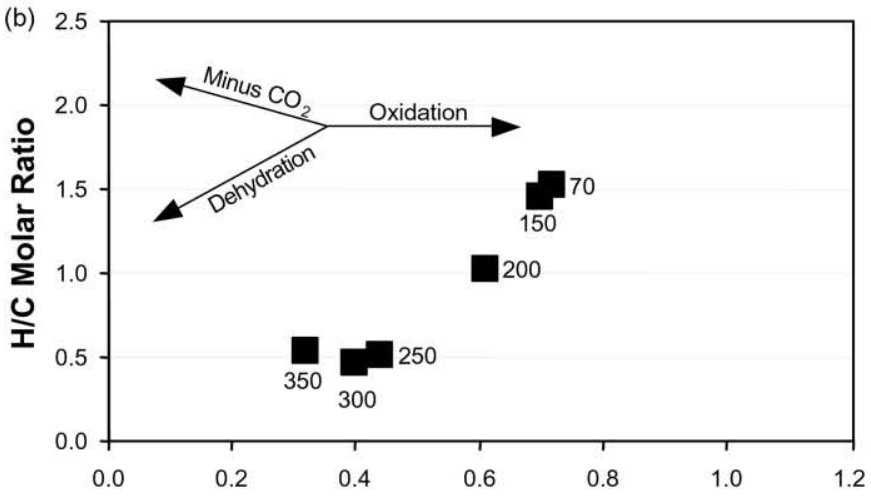

\section{$\boldsymbol{\Delta}$ Protein (Theoretical)}

$\square$ Lipid (Theoretical)

Carbohydrate (Theoretical)

:- Glucose (Theoretical)

Suaiacyl Lignin (Theoretical)

ZSyringyl Lignin (Theoretical)

- Pinus resinosa Sapwood (this study)

$\diamond$ Cellulose (van Krevelen 1950)

$\diamond$ Cellulose (Sekiguchi et al. 1983)

- Cellulose (Shafizadeh 1984)

O Wood (Shafizadeh 1984)

$\triangle$ Lignin (Shafizadeh 1984)

$\Delta$ Lignin (van Krevelen 1950)

Heated Pinus resinosa sapwood (this study)

\section{O/C Molar Ratio}

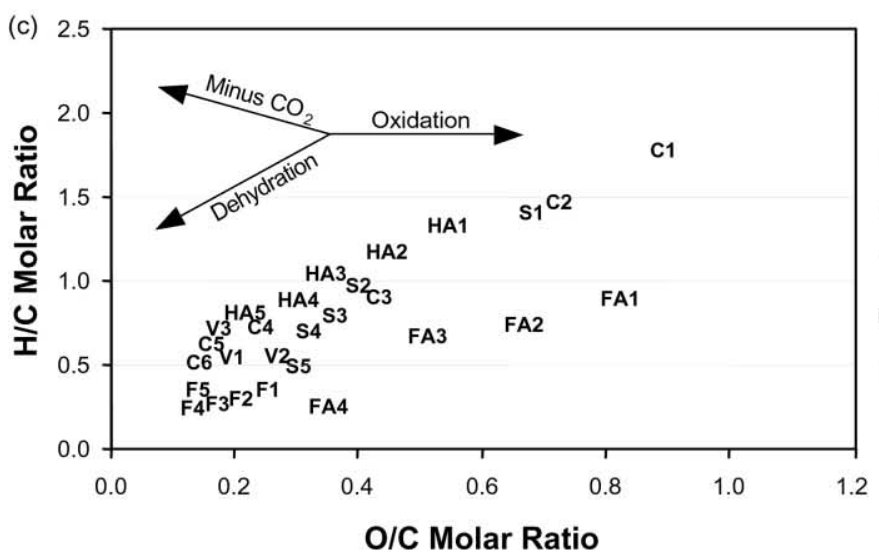

C Heated cellulose (Shafizadeh 1984)

S Heated Susuki grass (Shindo 1991)

F Grass char particle size fractions (Shindo 1991)

v Heated plant materials (Haumier and Zech 1995)

HA Heated soil derived humic acid (Almendros et al. 1990)

FA Heated soil derived fulvic acid (Almendros et al. 1990)

Fig. 1. Van Krevelen plots of (a) theoretical wood components (carbohydrate, lignin, lipid, and protein), measured wood components and unaltered wood, (b) Pinus resinosa sapwood samples from this study heated to the temperatures indicated by the numeric values adjacent to the data points, and (c) various additional organic materials. C1-C6: unheated cellulose and cellulose heated to 325, 350, 400,450 and $500{ }^{\circ} \mathrm{C}$. S1-S5: Susuki grass heated to $250^{\circ} \mathrm{C}$ for durations of $0,1,4,8$ and $12 \mathrm{~h}$. F1-F55: $>2,1-2,0.5-1,0.25-0.5$, and $<0.25 \mathrm{~mm}$ particle size fractions of charred plant materials produced by the burning in the field of dense Susuki plants. HA1-HA5: soil humic acids heated at $350{ }^{\circ} \mathrm{C}$ for $0,60,90,120$, and $150 \mathrm{~s}$. FAl-FA4: soil fulvic acids heated to $350{ }^{\circ} \mathrm{C}$ for $0,60,90$, and $120 \mathrm{~s}$. V1V3: charred grass burnt under ambient O2 concentration, soot from spruce wood burning, barley straw burnt under N2. For each set presented in (b) and (c), the increased extent of thermal alteration induced by either increased heating temperature or heating duration was associated with a progression to lower $\mathrm{H} / \mathrm{C}$ and $\mathrm{O} / \mathrm{C}$ values (movement from top-right to bottom-left of the figure). (van Krevelen, 1950; Sekiguchi et al., 1983; Shafizadeh, 1984; Shindo, 1991; Haumier and Zech, 1995; Almendros et al., 1990). 
Fig. $1 \mathrm{~b}$ and $\mathrm{c}$ are indicative of the van Krevelen trajectory associated with the loss of water and addition of oxygen to the molecular structures present in the samples. For all data sets presented in Fig. 1, the principal change in the elemental composition of the thermally altered residues was dehydration. In progressing from the residue remaining after heating at $300{ }^{\circ} \mathrm{C}$ to that remaining after heating to $350{ }^{\circ} \mathrm{C}$ and then to structures found in graphite, a loss of oxygen and a smaller loss of hydrogen would be required. Dehydration alone could not account for such changes; however, a combined loss of carbon dioxide or carbon monoxide with water would be consistent.

\section{2. ${ }^{13} C N M R$ errors and observability of $C$ in the samples}

Solid state ${ }^{13} \mathrm{C}$ NMR spectroscopy is a powerful technique for studying the structure of complex, high molecular weight organic materials. However, there are well-documented problems concerning its reliability (Kinchesh et al., 1995; Preston, 1996; Mao et al., 2000). Two of the main concerns, reproducibility and quantitation, were addressed by obtaining replicate spectra on one sample and carrying out spin counting experiments.

Due to the high cost and long acquisition times of NMR analysis, coupled with limited spectrometer availability, replicate measurements are rarely obtained. It must be noted, however, that the relatively large quantity of sample required for NMR analysis $(\sim 200$ $\mathrm{mg}$ ) ensures against reproducibility problems caused by sample inhomogeneity at scales much smaller than this. In other words, we would expect the reproducibility of solid state ${ }^{13} \mathrm{C}$ NMR spectroscopy to be good. This was confirmed explicitly for the wood heated to $200{ }^{\circ} \mathrm{C}$. CP spectra acquired three times on a single aliquot and on three separate aliquots were all similar (spectra not shown). The chemical shift values of the maxima of each resonance in all the spectra did not differ by more than 2 ppm. The integrated signal intensity in each spectral region expressed as a percentage of total signal intensity and the means and standards error for the replicated analyses were calculated (Table 4). Replicate analyses of the same aliquot of sample gave standard errors $\leqslant 0.3 \%$ of the total signal intensity for all spectral regions. The standard errors associated with the analysis of different aliquots of the same sample were larger, but were still $\leqslant 1.0 \%$ of the total signal intensity. As a result, variations in the percentage of signal intensity found within a given spectral region that are $>2.0 \%$ of total signal intensity can be considered significant for the CP analyses used in this study. The errors associated with the $\mathrm{BD}$ analysis were not determined due to time constraints on the NMR spectrometer.

Spin counting experiments (Smernik and Oades, $2000 \mathrm{a}, \mathrm{b})$ were used to address the issue of quantitation. The proportion of organic $\mathrm{C}$ observed, $\mathrm{C}_{\mathrm{obs}}$, in the $\mathrm{CP}$ and BD NMR analyses, relative to the observability of $\mathrm{C}$ in glycine, was quantified (Table 5). $\mathrm{C}_{\mathrm{obs}}$ for the unheated wood was high for both the $\mathrm{CP}$ and $\mathrm{BD}$ analyses, 0.91 and 0.90 , respectively. However, with increasing temperature of heating, $\mathrm{C}_{\mathrm{obs}}$ for the $\mathrm{CP}$ analysis decreased to a value of 0.36 for the wood heated to $350{ }^{\circ} \mathrm{C}$. For the $\mathrm{BD}$ analyses, a reduction in $\mathrm{C}_{\text {obs }}$ was not observed with increasing heating temperature. The reduction in observability was suspected to result from the progressive loss of $\mathrm{H}$ from the residue structure. A decreasing concentration of $\mathrm{H}$ within the residues would

Table 4

Estimates of the errors associated with repeated $\mathrm{CP}{ }^{13} \mathrm{C}$ NMR analysis of the same aliquot (NMR spectrometer error) and different aliquots (NMR spectrometer + sample preparation error) of the wood sample heated to constant mass at $200{ }^{\circ} \mathrm{C}$

\begin{tabular}{|c|c|c|c|c|c|c|c|c|c|}
\hline & & \multicolumn{8}{|c|}{ Percentage of the total acquired CP signal intensity found in each chemical shift region (ppm) } \\
\hline & & $0-45$ & $45-65$ & $65-95$ & $95-110$ & $110-145$ & $145-165$ & $165-190$ & $190-215$ \\
\hline \multirow{5}{*}{$\begin{array}{l}\text { Analysis of the } \\
\text { same aliquot } \\
\text { of sample }\end{array}$} & Rep1 & 10.1 & 7.7 & 38.1 & 9.1 & 22.6 & 9.2 & 5.6 & 2.1 \\
\hline & Rep2 & 9.8 & 7.8 & 38.2 & 9.2 & 22.3 & 8.7 & 5.4 & 2.1 \\
\hline & Rep3 & 10.0 & 7.5 & 37.9 & 9.3 & 21.8 & 8.6 & 6.3 & 1.9 \\
\hline & Mean $^{\mathrm{a}}$ & 10.0 & 7.7 & 38.0 & 9.2 & 22.2 & 8.8 & 5.8 & 2.1 \\
\hline & StdErr ${ }^{\mathrm{b}}$ & 0.08 & 0.07 & 0.09 & 0.06 & 0.24 & 0.18 & 0.26 & 0.05 \\
\hline \multirow{5}{*}{$\begin{array}{l}\text { Analysis of } \\
\text { different } \\
\text { aliquots } \\
\text { of the same } \\
\text { sample }\end{array}$} & Rep1 & 7.9 & 6.5 & 36.2 & 9.1 & 22.9 & 9.7 & 5.8 & 2.0 \\
\hline & Rep2 & 11.3 & 8.1 & 38.2 & 9.1 & 19.8 & 7.5 & 4.5 & 1.5 \\
\hline & Rep3 & 10.1 & 7.7 & 38.1 & 9.1 & 22.6 & 9.2 & 5.6 & 2.1 \\
\hline & Mean $^{\mathrm{a}}$ & 9.7 & 7.4 & 37.5 & 9.1 & 21.7 & 8.8 & 5.3 & 1.9 \\
\hline & StdErr ${ }^{b}$ & 1.00 & 0.50 & 0.65 & 0.01 & 0.99 & 0.66 & 0.41 & 0.18 \\
\hline
\end{tabular}

\footnotetext{
a Mean percentage of the total signal intensity found in each chemical shift region.

b Standard error of the percentage of the total signal intensity found in each chemical shift region.
} 
reduce the efficiency of the cross polarisation process in the CP pulse sequence. The creation of free radicals stabilised by the highly conjugated aromatic structures thought to be prevalent in charred materials would also have the potential to decrease the observability of carbon in the heated residues. Smernik et al. (2002a,b) have performed a detailed examination of the mechanisms that account for the decrease in $\mathrm{CP}-\mathrm{C}_{\text {obs }}$ with increasing extent of thermal alteration.

\subsection{Changes in chemical structure induced by thermal alteration}

\subsubsection{Cross polarisation and Bloch decay ${ }^{13} \mathrm{C} N M R$ analyses}

The solid-state CP ${ }^{13} \mathrm{C}$ NMR spectra acquired for the unaltered and thermally altered sapwood showed significant changes in both the chemical shift values of the resonances (Fig. 2) and the proportion of total signal intensity found in each chemical shift region (Fig. 3a) with increased heating temperature. No differences in the chemical shift values or proportions of total signal intensity were noted on heating the wood dried at 70 $150{ }^{\circ} \mathrm{C}$ and the spectra were typical of that obtained for samples of undecomposed wood (Hedges et al., 1985; Preston et al., 1990, 1998; Martínez et al., 1991; Baldock and Preston, 1995). The major resonances in the O-alkyl region $(64,74$, and $84 \mathrm{ppm})$ and the presence of a significant di-O-Alkyl resonance at 105 ppm are characteristic of cellulose (Maciel et al., 1982; VanderHart and Attala, 1984). The presence of resonances at 23 and 173 ppm likely arise from the acetate and carboxyl groups found in hemicellulose structures. Resonances at 56 (a shoulder on the $63 \mathrm{ppm}$ resonance), 131, and 148 ppm are indicative of the methoxyl, aryl and O-aryl C associated with lignin (Hatfield et al., 1987; Hatcher, 1987).

Significant changes in the distribution of signal intensity and the chemical shift values of some resonances

\section{Table 5}

Proportion of organic $\mathrm{C}$ observed, $\mathrm{C}_{\mathrm{obs}}$, in unaltered and thermally altered wood using $\mathrm{CP}$ and $\mathrm{BD}$ solid-state ${ }^{13} \mathrm{C}$ NMR analyses and proton relaxation rates, $\mathrm{T}_{1} \rho \mathrm{H}$ and $\mathrm{T}_{1} \mathrm{H}$

\begin{tabular}{lllll}
\hline $\begin{array}{l}\text { Heating } \\
\text { temperature }\left({ }^{\circ} \mathrm{C}\right)\end{array}$ & $\begin{array}{l}\mathrm{CP} \\
\mathrm{C}_{\text {obs }}\end{array}$ & $\begin{array}{l}\mathrm{BD} \\
\mathrm{C}_{\mathrm{obs}}\end{array}$ & $\mathrm{T}_{1} \rho \mathrm{H}(\mathrm{ms})$ & $\begin{array}{l}\mathrm{T}_{1} \mathrm{H} \\
(\mathrm{s})\end{array}$ \\
\hline 70 & 0.91 & 0.90 & $6.8(6.4-7.2)$ & 0.10 \\
150 & 0.91 & 0.98 & $6.2(6.0-6.4)$ & 0.11 \\
200 & 0.76 & 0.90 & $5.0(4.8-5.2)$ & 0.07 \\
250 & 0.44 & 0.86 & $4.7(4.4-5.1)$ & 0.01 \\
300 & 0.32 & 0.93 & $5.1(4.7-5.6)$ & 0.01 \\
350 & 0.36 & 0.93 & $3.1(2.9-3.4)$ & 0.01 \\
\hline
\end{tabular}

Values in parentheses appearing after the values of $\mathrm{T}_{1} \rho \mathrm{H}$ are the upper and lower limits of the $95 \%$ confidence interval of $\mathrm{T}_{1} \rho \mathrm{H}$. were initiated on heating at $200{ }^{\circ} \mathrm{C}$. The percentage of signal intensity associated with cellulose and hemicellulose structures (O-alkyl and di-O-alkyl chemical shift regions) was reduced from 70 to $46 \%$. The signal intensity initially associated with lignin (aryl and O-aryl chemical shift regions) increased from 15 to $30 \%$ and that of carbonyl carbon increased from 1 to $5 \%$. In addition, the chemical shift at which the maximum aryl signal intensity was observed decreased from 131 to 128 ppm and the width of the carboxyl resonance increased.

At heating temperatures $\geqslant 250{ }^{\circ} \mathrm{C}$ the spectra were dominated by large resonances in the aryl and O-aryl chemical shift regions. The contribution of aryl $\mathrm{C}$ increased to $64 \%$ of the total signal intensity and that of O-aryl C increased to $19 \%$ and then decreased to $13 \%$. Concomitantly, the proportion of signal intensity found in the O-alkyl and di-O-alkyl $\mathrm{C}$ spectral regions

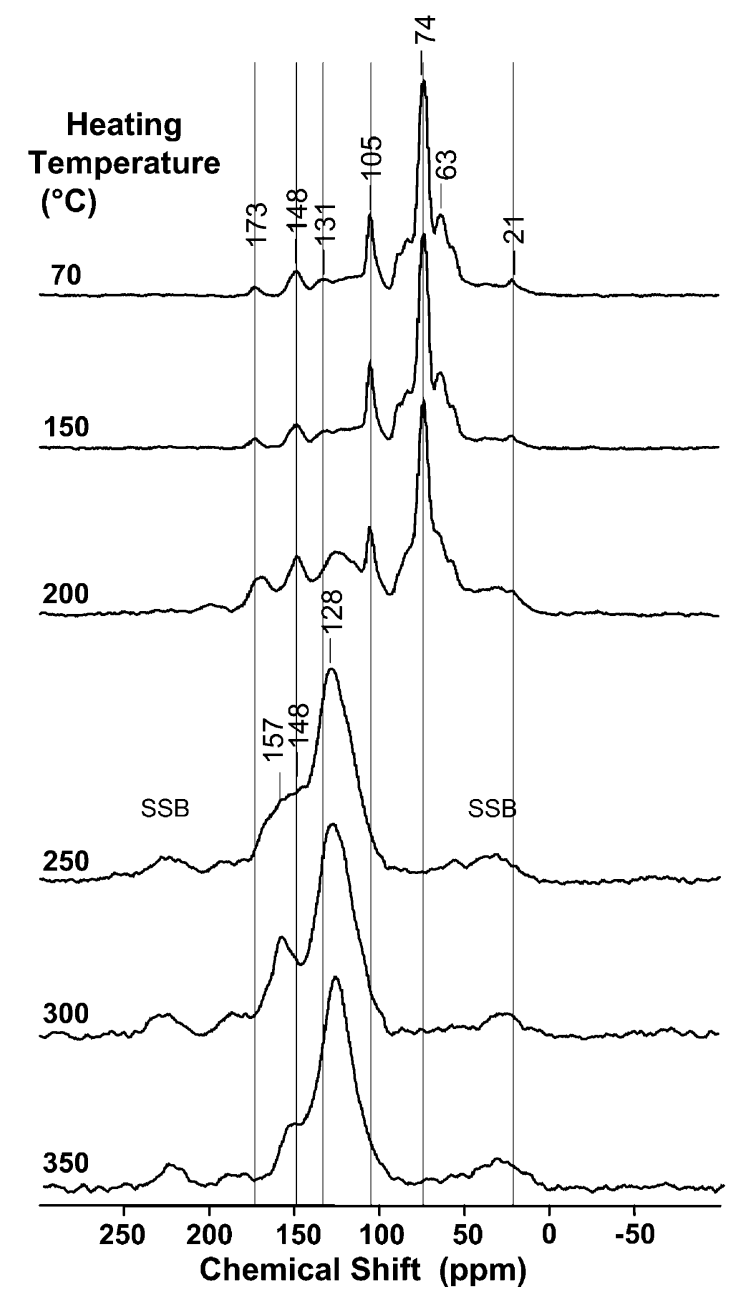

Fig. 2. Solid-state cross polarisation ${ }^{13} \mathrm{C}$ NMR spectra of Pinus resinosa sapwood heated to constant mass at different temperatures. SSB refers to spinning side bands located approximately $100 \mathrm{ppm}$ from their parent resonance. 
decreased to $<10 \%$. A small increase in the percentage of carboxyl $\mathrm{C}$ was also evident. In progressing from heating temperatures of $200-350{ }^{\circ} \mathrm{C}$, significant changes in the chemical shift values of the aryl and O-aryl $\mathrm{C}$ resonances were also observed. For the aryl-C resonance, a gradual shift from 131 to 127 ppm was noted. For the O-aryl resonance, there was a transition from $148 \mathrm{ppm}$ at $200{ }^{\circ} \mathrm{C}$ to a mixture of two resonances at 150 and $160 \mathrm{ppm}$ at $250{ }^{\circ} \mathrm{C}$, to a dominance of a resonance at $157 \mathrm{ppm}$ at $300{ }^{\circ} \mathrm{C}$, and finally to a less distinct resonance at $157 \mathrm{ppm}$ at $350^{\circ} \mathrm{C}$.

The changes in chemical shift values of the maxima of the resonances within the BD spectra were consistent with those observed for the CP spectra (Figs. 2 and 4). However, differences in the distribution of signal intensity among the chemical shift regions were evident. For the sapwood heated to $70{ }^{\circ} \mathrm{C}$, the distribution of signal intensity amongst the chemical shift regions was virtually identical in the $\mathrm{CP}$ and $\mathrm{BD}$ analyses. After heating to $150{ }^{\circ} \mathrm{C}$, less $\mathrm{O}$-alkyl and more aryl $\mathrm{C}$ was observed in the BD than $\mathrm{CP}$ spectra. This trend was enhanced after heating the wood to $200{ }^{\circ} \mathrm{C}$, with the BD spectrum containing 8\% less O-alkyl $\mathrm{C}$ and $6 \%$ more aryl plus O-aryl C. At heating temperatures $\geqslant 250{ }^{\circ} \mathrm{C}$, the distribution of the different types of $\mathrm{C}$ in the $\mathrm{CP}$ and $\mathrm{BD}$ spectra was similar. Thus, at temperatures $\geqslant 250{ }^{\circ} \mathrm{C}$, although the $\mathrm{CP}$ analyses were not quantitative, an adequate distribution of signal intensity was acquired. This observation resulted from the fact that only charred materials were left after heating to
$250{ }^{\circ} \mathrm{C}$. Where charred materials represent only a fraction of the organic $\mathrm{C}$ present in a sample, such as in some mineral soils, the CP analysis will not give an accurate representation of the distribution of the various forms of $\mathrm{C}$ because of the low observability of char $\mathrm{C}$ relative to other forms of $\mathrm{C}$. This is illustrated by the small variation in the distribution of signal intensity noted between the $\mathrm{CP}$ and $\mathrm{BD}$ analyses of the wood heated to $200{ }^{\circ} \mathrm{C}$ where the formation of charred materials is just beginning and significant quantities of the other types of $\mathrm{C}$ still remain.

Given the dominance of aryl $\mathrm{C}$ in charred structures, the chemical changes associated with the charring process are often expressed in terms of the change in the proportion of aryl $\mathrm{C}$. The accumulation of aryl $\mathrm{C}$ with increased heating temperatures followed a similar pattern to that observed during the heating of cellulose (Shafizadeh, 1984; Pastorova et al., 1994) and kerogen (Dennis et al., 1982) (Fig. 5a). Some of the variation of the different data sets along the heating temperature axis undoubtedly arises from the variations in the length of exposure time at each temperature. In addition, the initial presence of aryl $\mathrm{C}$ in the sapwood used in this study and kerogen used by Dennis et al. (1982) means that at least at the lower heating temperatures, the aryl $\mathrm{C}$ is a mixture of lignin/kerogen derived aryl $\mathrm{C}$ originally present in the samples and that produced by heating. Similar progressive increases in aryl $\mathrm{C}$ content with increasing heating were noted when samples of humic and fulvic acid (Almendros et al., 1990, 1992) and

(a)

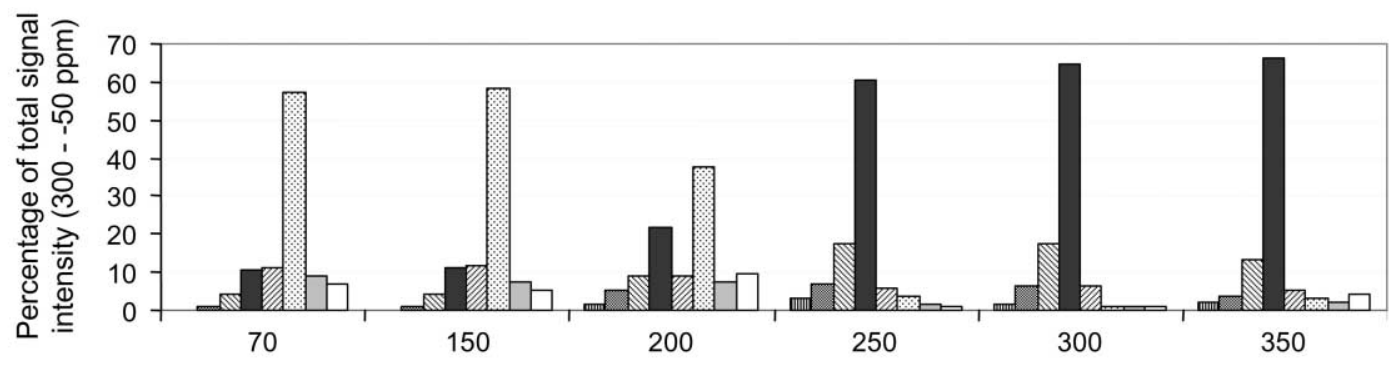

(b)

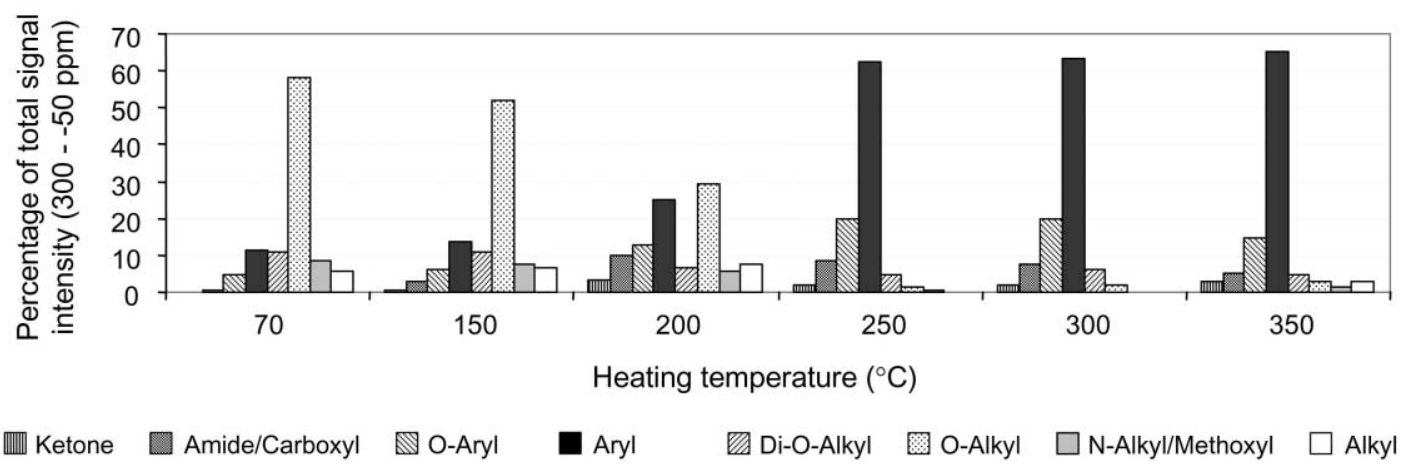

Fig. 3. Distribution of total ${ }^{13} \mathrm{C}$ NMR signal intensity into chemical shift regions for the (a) cross polarisation and (b) empty rotor corrected Bloch decay analyses of Pinus resinosa sapwood heated to different temperatures. 
ryegrass leaves (Knicker et al., 1996) were heated for increasing durations at $350{ }^{\circ} \mathrm{C}$.

Formation of furan-like materials in the O-aryl spectral region is evident for materials containing significant quantities of cellulose (Shafizadeh, 1984; Pastorova et al., 1994). The oxygenated carbons in benzofuran and dibenzofuran resonate at chemical shift values of 155 and $156 \mathrm{ppm}$, respectively. The transition from an O-aryl resonance at $148 \mathrm{ppm}$ after heating to $200{ }^{\circ} \mathrm{C}$ to a resonance at $157 \mathrm{ppm}$ after heating to $300^{\circ} \mathrm{C}$ is consistent with a shift from the $\mathrm{O}$-aryl $\mathrm{C}$ of the guaiacyl monomer in gymnosperm lignin to furan $\mathrm{C}$ generated during the heating of cellulose. Variations in the signal intensity in the O-aryl region of the sapwood spectra followed a similar pattern to that observed by

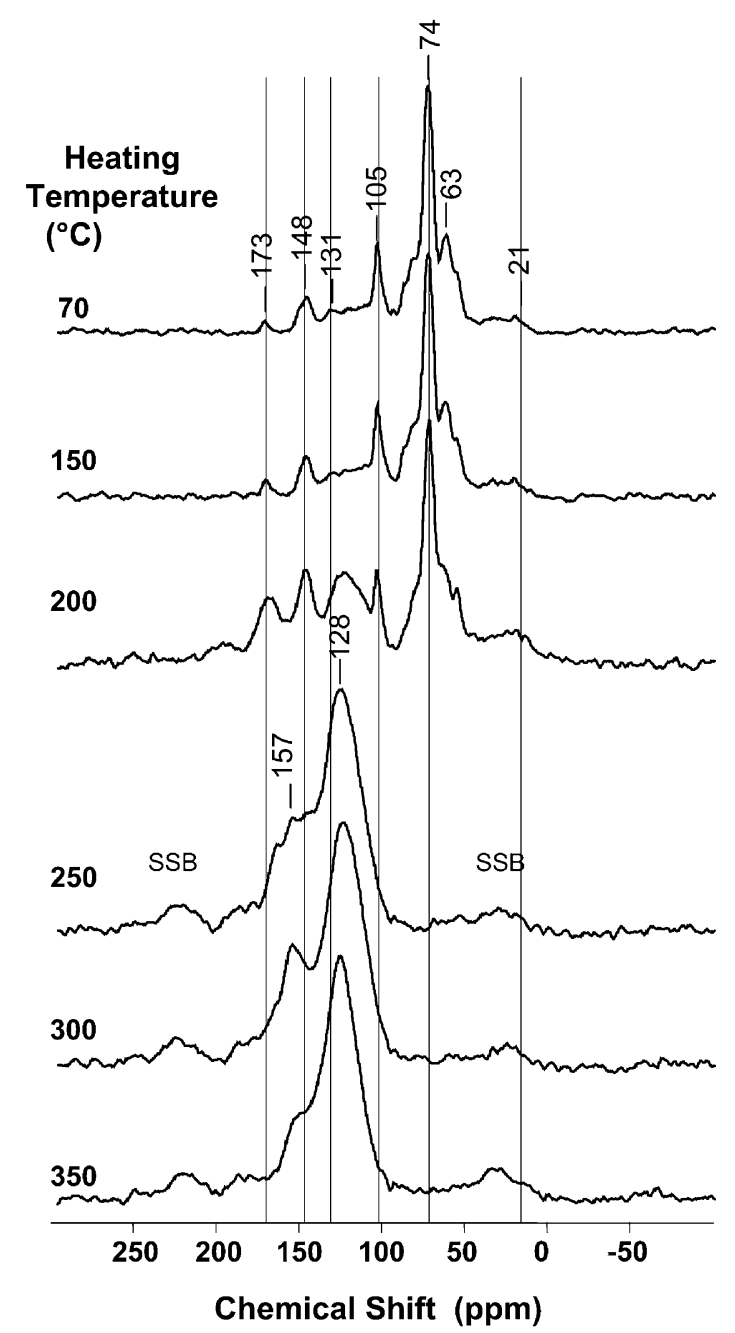

Fig. 4. Solid-state Bloch decay ${ }^{13} \mathrm{C}$ NMR spectra (corrected for empty rotor signals) of Pinus resinosa sapwood heated at different temperatures to constant mass. SSB refers to spinning side bands located approximately $100 \mathrm{ppm}$ from their parent resonance.
Shafizadeh (1984) and Pastorova et al. (1994) during the heating of cellulose (Fig. 5b). As noted for aryl C, variations in the placement of the data sets on the heating temperature axis would be expected given the differences in heating treatments. The lack of formation of O-aryl C at $157 \mathrm{ppm}$ for kerogen that contained little if any carbohydrate (Dennis et al., 1982) supports the proposal that the $\mathrm{O}$-aryl $\mathrm{C}$ present in the sapwood heated to temperatures $\geqslant 300{ }^{\circ} \mathrm{C}$ was derived from the thermal alteration of cellulose.

\subsection{2. $N M R$ relaxation rates}

Proton NMR relaxation rates play a critical role in the sensitivity and quantitation of solid-state $\mathrm{CP}{ }^{13} \mathrm{C}$ NMR spectroscopy. The static frame spin-lattice relaxation rate $\left(1 / \mathrm{T}_{1} \mathrm{H}\right)$ determines the minimum recycle delay (i.e. time between consecutive scans) possible without losing signal through saturation; a recycle delay of $>10 \times \mathrm{T}_{1} \mathrm{H}$ is generally considered adequate. Proton spin-lattice relaxation in the rotating frame $\left(\mathrm{T}_{1} \rho \mathrm{H}\right.$ relaxation) causes signal attenuation in $\mathrm{CP}$ experiments. The spin counting methodology used here requires measurement of $\mathrm{T}_{1} \rho \mathrm{H}$ for each sample to correct for this signal loss. However, quite apart from being necessary for ensuring optimal acquisition, measurement of proton relaxation rates provides another set of parameters with which to compare the thermally treated woods, quite independent of the chemical shift parameters discussed above.

Both $T_{1} H$ and $T_{1} \rho H$ decreased with increasing heating temperature (Table 5). This can be attributed to an increase in the concentration of unpaired electrons (free radicals) in the heated samples. The electronic spins of free radicals provide a very efficient mechanism for the relaxation of nuclear spins. $\mathrm{T}_{1} \mathrm{H}$ was more sensitive than $\mathrm{T}_{1} \rho \mathrm{H}$ to heating temperature, with a 10 -fold decrease evident between the 150 and $250{ }^{\circ} \mathrm{C}$ heat-treated samples. This temperature range corresponds to where the greatest changes were observed in the $\mathrm{CP}$ and $\mathrm{BD}$ spectra (Figs. 2 and 4). No further decreases in $\mathrm{T}_{1} \mathrm{H}$ were observed on heating above $250{ }^{\circ} \mathrm{C} . \mathrm{T}_{1} \rho \mathrm{H}$ showed a more gradual decrease with heating temperature, with a large and significant decrease evident on heating from $300-350{ }^{\circ} \mathrm{C}$. The greater sensitivity of $\mathrm{T}_{1} \mathrm{H}$ over $\mathrm{T}_{1} \rho \mathrm{H}$ to the concentration of unpaired spins has been noted previously (Smernik and Oades, 1999, 2000c).

\subsubsection{DRIFT analyses}

The DRIFT spectra acquired for sapwood heated to 70 and $150^{\circ} \mathrm{C}$ were similar (Fig. 6) and resembled that collected for other gynosperms (Pinus roxgurghii and Cupressus lusitanica) (Pandey, 1999). The 70 and $150{ }^{\circ} \mathrm{C}$ spectra were characterised by strong hydrogen bonded $\mathrm{O}-\mathrm{H}$ stretching near $3420 \mathrm{~cm}^{-1}, \mathrm{C}-\mathrm{H}$ stretching near $2900 \mathrm{~cm}^{-1}, \mathrm{C}=\mathrm{O}$ near $1740 \mathrm{~cm}^{-1}$, and $\mathrm{C}=\mathrm{C}$ near $1510 \mathrm{~cm}^{-1}$. Many additional absorbances derived from 
(a)

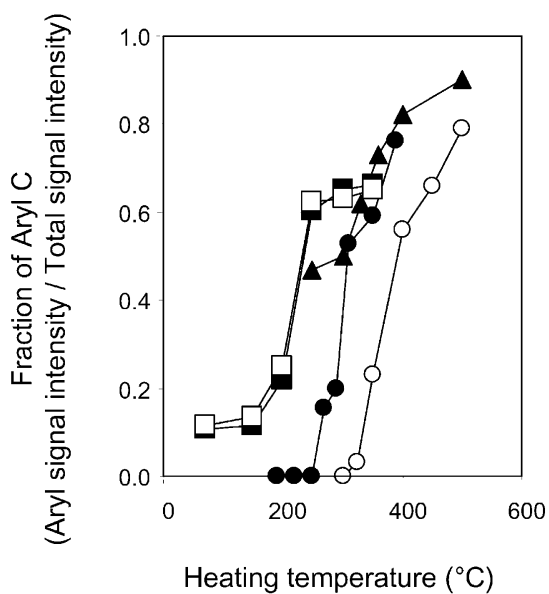

(b)

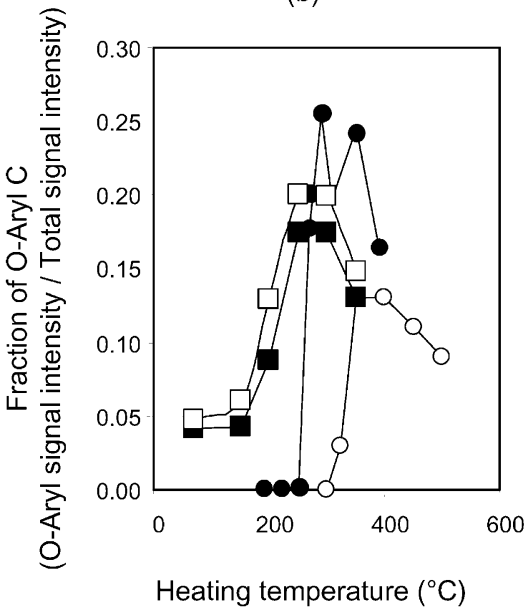

Pinus resinosa sapwood (CP data - this study)

Pinus resinosa sapwood (BD data - this study)

Cellulose

(Pastorova et al. 1994)

- - Cellulose

(Shafizadeh 1984)

Kerogen

(Dennis et al. 1982)

Fig. 5. Changes in the proportion of total signal intensity attributable to (a) Aryl C and (b) O-Aryl C. The conditions used for the heating process were as follows: Pastrova et al. (1994) 150 minutes under N2, Shafizadeh (1984) 5 minutes, and Dennis et al. (1982) 24 hours under $\mathrm{N}_{2}$; (b) does not contain data from Dennis et al. (1982) because no distinct resonances or shoulders were noted in the OAryl region of the spectra presented for the heated kerogen.

contributions of the various vibration modes of $\mathrm{C}$ originating from carbohydrates and lignin were observed in the 1800-500 $\mathrm{cm}^{-1}$ spectral region (Shafizadeh, 1984; Pandey, 1999; Martínez et al., 1999). Heating to temperatures $\geqslant 200{ }^{\circ} \mathrm{C}$ resulted in significant changes to the DRIFT spectra including:

(1) a broadened and decreased intensity of the O-H stretching signal $\left(3400 \mathrm{~cm}^{-1}\right)$,

(2) an increase in signal intensity due to aromatic ring C-H $\left(3090 \mathrm{~cm}^{-1}\right)$,

(3) an almost complete loss of intensity for $\mathrm{C}-\mathrm{H}$ stretching $\left(2900 \mathrm{~cm}^{-1}\right)$,

(4) a disappearance of intensity at 2130 and 2054 $\mathrm{cm}^{-1}$,

(5) a loss of signals derived from amines and amides $\left(1660 \mathrm{~cm}^{-1}\right)$

(6) a decrease in $\mathrm{C}=\mathrm{O}$ relative to $\mathrm{C}=\mathrm{C}$ (1740 and $1610 \mathrm{~cm}^{-1}$, respectively),

(7) a progressive coalescence of the various carbohydrate and lignin derived signals between $1600-900 \mathrm{~cm}^{-1}$ into two signals centred at 1430 and $1275 \mathrm{~cm}^{-1}$, and

(8) an increase in the intensity of signals near 825 and $765 \mathrm{~cm}^{-1}$ indicative of aryl $\mathrm{C}-\mathrm{H}$ and/or aryl $\mathrm{C}-\mathrm{O}$ groups.

The decreased intensity for $\mathrm{O}-\mathrm{H}$ and $\mathrm{C}-\mathrm{H}$ groups with increasing heating temperature was consistent with the dehydration reactions suggested by the elemental data. The decrease in $\mathrm{C}=\mathrm{O}$ relative to $\mathrm{C}=\mathrm{C}$ in progressing from a heating temperature of $250-350{ }^{\circ} \mathrm{C}$ was

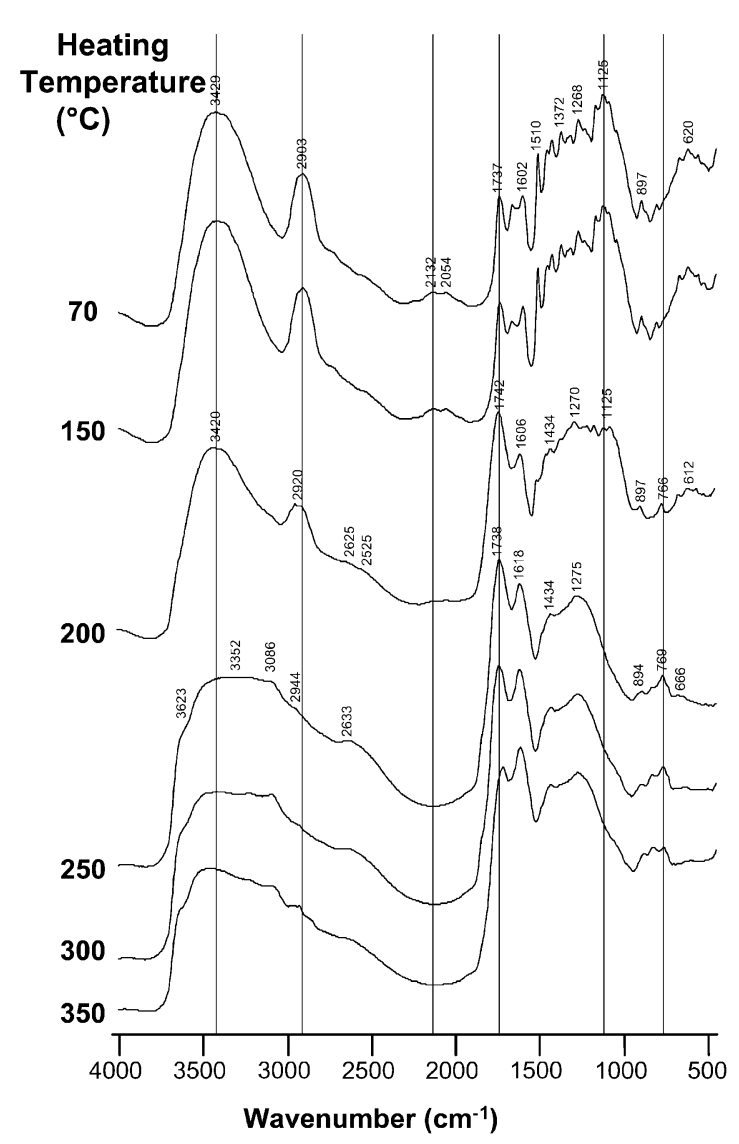

Fig. 6. DRIFT spectra of Pinus resinosa sapwood heated to constant mass at different temperatures. 
also consistent with the loss of oxygen from the structure of the residues suggested by the changes in $\mathrm{H} / \mathrm{C}$ and $\mathrm{O} / \mathrm{C}$ elemental ratios. The loss of signals typically associated with carbohydrate and lignin, particularly that at $1510 \mathrm{~cm}^{-1}$ due to aryl ring vibrations in guaiacyl lignin (Martínez et al., 1999), accompanied by a maintenance of signals associated with aryl ring structures was consistent with the conversion of carbohydrate and lignin $\mathrm{C}$ into aryl structures typical of charred materials suggested by the ${ }^{13} \mathrm{C}$ NMR analyses. The signals near 826 and $767 \mathrm{~cm}^{-1}$ were consistent with oxygenated aryl groups such as those found in quinone and furan-like structures (van der Marel and Beutelspacher, 1976). The changes observed in the DRIFT spectra were similar to those noted on heating forest soil humus (Pietikäinen et al., 2000), sugar cane bagasse (Bilba and Ouensanga, 1996), cellulose and wood (Shafizadeh, 1984).

\subsection{Bioavailability of unaltered and thermally altered sapwood}

The type of organic C (glucose, cellulose, unaltered wood, or thermally altered wood) added to the incubation vessels influenced the proportion of added $\mathrm{C}$ that was mineralised (Fig. 7).

Approximately $85 \%$ of the glucose $\mathrm{C}$ and $74 \%$ of the cellulose-C were mineralised over the 120 day incubation, indicating that the incubation conditions were conducive to high rates of decomposition and mineralisation provided an available organic substrate was present. The proportion of added organic $\mathrm{C}$ mineralised from the unaltered sapwood $(20 \%)$ was less than that measured for the treatments where glucose or cellulose were added. The proportion of added $\mathrm{C}$ mineralised was reduced to $13 \%$ for the sapwood heated to $150{ }^{\circ} \mathrm{C}$. The mineralisation of added $\mathrm{C}$ was reduced further to values $<2 \%$ by heating the sapwood to temperatures $\geqslant 200{ }^{\circ} \mathrm{C}$. The reduction in capacity to mineralise the $\mathrm{C}$ remaining after heating to temperatures $\geqslant 200{ }^{\circ} \mathrm{C}$ corresponded to the temperature where significant chemical changes were initiated, particularly a reduction in O-alkyl C (principally derived from cellulose and hemicellulose) and the formation of condensed aryl and O-aryl furan structures.

Numerous studies have measured reductions in the amount or activity of the soil microbial biomass present in mineral soils and forest humus layers subsequent to laboratory heating or prescribed burning (Almendros et al., 1984; Diaz-Raviña et al., 1992, 1996; Grasso et al., 1996; Fernández et al., 1997; Acea and Carballas, 1999). Fritze et al. (1994b) and Pietikäinen and Fritze (1995) found that the practice of prescribed burning reduced the mineralisation of $\mathrm{C}$ from forest humus layers by as much as $70 \%$ relative to unburnt sites. In samples where the indigenous microbial population was exposed to the heating treatment, the reductions in microbial activity or biomass may have resulted from an influence of the heating process on the amount of viable microbial biomass (Labeda et al., 1975; Attiwill and Leeper, 1987; Acea and Carballas, 1999), the community structure of the microbial biomass (Bissett and Parkinson, 1980; Entry et al., 1986; Pietikäinen and Fritze, 1995; Pietikäinen et al., 2000) or changes to the chemical composition of the organic materials that alter their ability to act as a microbial substrate (Almendros et al., 1990;

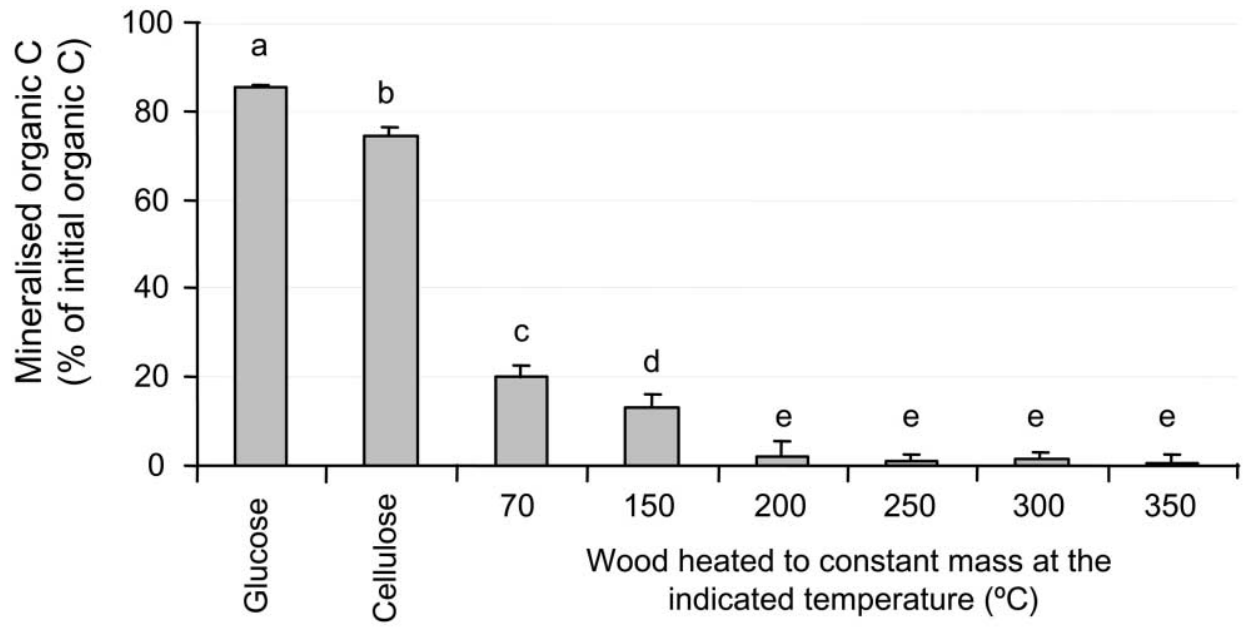

\section{Organic material added to the incubation vessels}

Fig. 7. Mineralisation of organic carbon contained in glucose, cellulose, and Pinus resinosa sapwood heated to thermal equilibrium at increasing temperatures. Error bars indicate the standard deviation of the means. Values with different letters are significantly different at $\alpha=0.05$ as determined by a Tukey's HSD post hoc analysis. 
Bååth et al., 1995; Pietikäinen and Fritze, 1995; Knicker et al., 1996; Fernández et al., 1997; Pietikäinen et al., 2000).

In the current study, the use of a common inoculant derived from a decomposing Pinus resinosa log and not exposed to the heating treatment, has meant that the observed changes in mineralisation could be completely attributed to the influence that the heating treatments had on the chemical nature of the sapwood. Variations in the chemical composition of forest humus as assessed using near-infrared spectra were shown to account for over $80 \%$ of the variation in basal respiration (Nilsson et al., 1992; Palmborg and Nordgren, 1993) and over $80 \%$ in the variation in microbial biomass $\mathrm{C}$ in burnt soils (Fritze et al., 1994a; Pietikäinen and Fritze, 1995). In natural systems where burning has resulted in a partial or complete sterilization of a soil layer, a recolonisation of the soil by organisms located below or adjacent to the heated zone is inevitable. The type of recolonising organisms and the rate of recolonisation will be influenced by the quality of the residual organic materials as defined by their chemical composition.

\section{Summary and conclusions}

Thermal treatment induced significant variations in the chemical composition of the Pinus resinosa sapwood at temperatures $\geqslant 200{ }^{\circ} \mathrm{C}$. Changes in elemental concentrations and molar elemental ratios at temperatures $\leqslant 300{ }^{\circ} \mathrm{C}$ were consistent with dehydration and the formation of unsaturated structures. In progressing to the residues remaining after heating at $350{ }^{\circ} \mathrm{C}$ and then on to structures similar to that found in highly thermally altered material, a net loss of oxygen from the structure was required, suggesting a loss of carbon dioxide or a combination of carbon monoxide and water. NMR analyses indicated that results acquired using the conventional cross polarisation pulse sequence, although representative, were not quantitative. Quantitative observation of the carbon found in the charred structures required the use of Bloch decay analyses. The infrared and NMR analyses indicated that the changes in the chemical composition with increasing heating temperature included a conversion of $\mathrm{O}$ alkyl $\mathrm{C}$ to aryl and O-aryl furan-like structures, consistent with results from work examining the chemical changes associated with thermal treatment of cellulose. The chemical changes induced by thermal treatment significantly reduced the ability of a microbial inoculum derived from decomposing Pinus resinosa wood to mineralise carbon contained in the charred residues. The $\mathrm{C}$ mineralisation rate constants decreased by an order of magnitude with increasing heating temperature.

\section{Acknowledgements}

Technical assistance was provided by Mr. Russell Miller in the collection, preparation and heating of the wood samples, Ms. Fiona McBain in maintaining the incubation experiment and Mr. Jack Gudeman and Mr. Ken Prentice for determining the ash content of the heated wood. Mr. Les Janik provided assistance with the acquisition and interpretation of the DRIFT analyses.

\section{Associate Editor-K. Schmidt-Rohr}

\section{References}

Acea, M.J., Carballas, T., 1999. Microbial fluctuations after soil heating and organic amendment. Bioresource Technology 67, 65-71.

Alla, M., Lippmaa, E., 1976. High resolution broad line 13C NMR and relaxation in solid norbornadiene. Chemical Physics Letters 37, 260-264.

Almendros, G., González-Vila, F.J., Martin, F., 1990. Fire induced transformation of soil organic matter from and oak forest: an experimental approach to the effects of fire on humic substances. Soil Science 149, 158-168.

Almendros, G., González-Vila, F.J., Martín, F., Fründ, R., Lüdemann, H.-D., 1992. Solid state NMR studies of fireinduced changes in the structure of humic substances. The Science of the Total Environment 117/118, 63-74.

Almendros, G., Polo, A., Ibanez, J.J., Lobo, M.C., 1984. Conribución al estudio de la infuencia de los incendios forestales en las caracteristicas de la materia orgánica del suelo. Revue d'Ecologie et Biologie du Sol 21, 7-20.

Attiwill, P.M., Leeper, G.W., 1987. Forest Soils and Nutrient Cycles. Melbourne University Press, Melbourne, Victoria, Australia.

Bååth, E., Frostegård, Å., Pennanen, T., Fritze, H., 1995. Microbial community structure and $\mathrm{pH}$ response in relation to soil organic matter quality in wood-ash fertilized, clear-cut or burned coniferous forest soils. Soil Biology and Biochemistry $27,229-240$.

Baldock, J.A., Preston, C.M., 1995. Chemistry of carbon decomposition processes in forests as revealed by solid-state carbon-13 nuclear magnetic resonance. In: McFee, W.W., Kelly, J.M. (Eds.), Carbon Forms and Functions in Forest Soils. Soil Science Society of America, Inc, Madison, WI, pp. 89-117.

Bessie, W.C., Johnson, E.A., 1995. The relative importance of fuels and weather on fire behaviour in subalpine forests. Ecology 76, 747-762.

Bilba, K., Ouensanga, A., 1996. Fourier transform infrared spectroscopic study of thermal degradation of sugar cane bagasse. Journal of Analytical and Applied Pyrolysis 38, 61-73.

Bissett, J., Parkinson, D., 1980. Long-term effects of fire on the composition and activity of the soil microflora of a subalpine coniferous forest. Canadian Journal of Botany 58, 1704-1721.

Dennis, L.W., Maciel, G.E., Hatcher, P.G., Simoneit, B.R., 1982. ${ }^{13} \mathrm{C}$ nuclear magnetic resonance studies of kerogen from Cretaceous black shales thermally altered by basaltic 
intrusions and laboratory simulations. Geochimica et Cosmochimica Acta 46, 901-907.

Diaz-Raviña, M., Prieto, A., Acea, M.J., Carballas, T., 1992. Fumigation-extraction method to estimate microbial biomass in heated soils. Soil Biology and Biochemistry 24, 259-264.

Díaz-Raviña, M., Prieto, A., Bååth, E., 1996. Bacterial activity in a forest soil after soil heating and organic amendments measured by thymidine and leucine incorporation techniques. Soil Biology and Biochemistry 28, 419-426.

Entry, J.A., Stark, N.M., Loewenstein, H., 1986. Effect of timber harvesting on microbial biomass fluxes in a northern Rocky Mountain forest soil. Canadian Journal of Forest Research 16, 1076-1081.

Fernández, I., Cabaneiro, A., Carballas, T., 1997. Organic matter changes immediately after a wildfire in an Atlantic forest soil and comparison with laboratory heating. Soil Biology and Biochemistry 29, 1-11.

Fritze, H., Järvinen, P., Hiukka, R., 1994a. Near-infrared characteristics of forest humus correlate to soil respiration and microbial biomass in burnt soil. Biology and Fertility of Soils 18, 80-82.

Fritze, H., Smolander, A., Levula, T., Kitunen, V., Mälkönen, E., 1994b. Wood-ash fertilization and fire treatments in Scots pine forest stand: effects on the organic layer, microbial biomass, and microbial activity. Biology and Fertility of Soils 17, 57-63.

Gélinas, Y., Baldock, J.A., Hedges, J.I., 2001. Organic carbon composition of marine sediments: effects of oxygen exposure on oil generation potential. Science 294, 145-148.

Glaser, B., 1999. Eigenschaften und Stabilität des Humuskörpers der Indianerschwarzerden Amozoniens. Bayreuther Bodenkundliche Berichte 68.

Glaser, B., Balashov, W., Haumaier, L., Guggenberger, G., Zech, W., 2000. Black carbon in density fractions of anthropogenic soils of the Brazilian Amazon region. Organic Geochemistry $31,669-678$.

Glaser, B., Guggenberger, G., Zech, W., 2001a. Black carbon in sustainable soils of the Brazilian Amazon region. In: Smith, R.S., Spark, K.M. (Eds.), Understanding and Managing Organic Matter in Soils, Sediments and Waters. International Humic Substances Society, St. Paul, MN, USA, pp. 359-364.

Glaser, B., Haumaier, L., Guggenberger, G., Zech, W., 1998. Black carbon in soils: the use of benzenecaboxylic acids as specific markers. Organic Geochemistry 29, 811-819.

Glaser, B., Haumaier, L., Guggenberger, G., Zech, W., 2001 b. The 'Terra Preta' phenomenon: a model for sustainable agriculture in the humid tropics. Naturwissenschaften 88 , $37-41$.

Goldberg, E., 1985. Black Carbon in the Environment. John Wiley and Sons, New York, NY.

Grasso, G.M., Ripabelli, G., Sammareo, M.L., Mazzoleni, S., 1996. Effects of heating on the microbial population of a grassland soil. International Journal of Wildland Fire 6, 67-70.

Hatcher, P.G., 1987. Chemical structural studies of natural lignin by dipolar dephasing solid-state ${ }^{13} \mathrm{C}$ nuclear magnetic resonance. Organic Geochemistry 11, 31-39.

Hatfield, G.R., Maciel, G.E., Erbatur, O., Erbatur, G., 1987. Qualitative and quantitative analysis of solid lignin samples by carbon-13 nuclear magnetic resonance spectroscopy. Analytical Chemistry 59, 172-179.
Haumaier, L., Zech, W., 1995. Black carbon — possible source of highly aromatic components of soil humic acids. Organic Geochemistry 23, 191-196.

Hedges, J.I., Cowie, G.L., Ertel, J.R., Barbour, R.J., Hatcher, P.G., 1985. Degradation of carbohydrates and lignins in buried woods. Geochimica et Cosmochimica Acta 49, 701711.

Hellgren, O., Ingestad, T., 1996. A comparison between methods used to control nutrient supply. Journal of Experimental Botany 47, 117-122.

Hofrichter, M., Ziegenhagen, D., Sorge, S., Ullrich, R., Bublitz, F., Fritsche, W., 1999. Degradation of lignite (lowrank-coal) by lignolytic basidiomycetes and their peroxidase system. Applied Microbiology and Biotechnology 52, 78-84.

Jenkinson, D.S., Hart, P.B.S., Rayner, J.H., Parry, L.C., 1987. Modelling the turnover of organic matter in long-term experiments at Rothamsted. Intecol Bulletin 15, 1-8.

Johnson, E.A., 1992. Fire and Vegetation Dynamics. Studies from the North American Boreal Forest. Cambridge University Press, Cambridge, UK.

Jones, T.P., Chaloner, W.G., Kuhlbusch, T.A.J. (Eds.), 1997. Sedimental Records of Biomass Burning and Global Change. Springer-Verlag, New York.

Kinchesh, P., Powlson, D.S., Randall, E.W., 1995. ${ }^{13}$ C NMR studies of organic matter in whole soils: I. Quantitation possibilities. European Journal of Soil Science 46, 125-138.

Knicker, H., Almendros, G., González-Vila, F.J., Martin, F., Lüdeman, H.-D., 1996. ${ }^{13} \mathrm{C}$ - and ${ }^{15} \mathrm{~N}-\mathrm{NMR}$ spectroscopic examination of the transformation of organic nitrogen in plant biomass during thermal treatment. Soil Biology and Biochemistry 28, 1053-1060.

Labeda, D.P., Galkwill, D.L., Casida Jr., L.E., 1975. Soil sterilization effects on in situ indigenous microbial cells in soil. Canadian Journal of Microbiology 21, 263-269.

Maciel, G.E., Kolodziejski, W.L., Bertran, M.S., Dale, B.E., 1982. ${ }^{13} \mathrm{C}$ NMR and order in cellulose. Macromolecules 15, 686-687.

Mao, J.-D., Hu, W.-G., Schmidt-Rohr, K., Davies, G., Ghabbour, E.A., Xing, B., 2000. Quantitative characterization of humic substances by solid-state carbon-13 nuclear magnetic resonance. Soil Science Society of America Journal 64, 873-884.

Martínez, A.T., Almendros, G., González-Vila, F.J., Fründ, R., 1999. Solid-state spectroscopic analysis of lignins from several Austral hardwoods. Solid State Nuclear Magnetic Resonance 15, 41-48.

Martínez, A.T., González-Vila, A.E., Valmaseda, M., Dale, B.E., Lambregts, M.J., Haw, J.F., 1991. Solid-state NMR studies of lignin and plant polysaccharide degradation by fungi. Holzforschung 45, 49-54.

Nelson, B.C., Goñi, M.A., Hedges, J.I., Blanchette, R.A., 1995. Soft-rot fungal degradation of lignin in 2700 year old archaeological woods. Holzforschung 49, 1-10.

Nilsson, M., Korsman, T., Nordgren, A., Palmborg, C., Renberg, I.Ö.J., 1992. NIR spectroscopy used in the microbiological and environmental sciences. In: Hildrum, K.I., Isaksson, T., Næs, T., Tandgerg, A. (Eds.), Near Infra-red Spectroscopy. Horwood, London, pp. 229-234.

Nordin, A., Uggla, C., Näsholm, T., 2001. Nitrogen forms in bark, wood and foliage of nitrogen fertilized Pinus sylvestris. Tree Physiology 21, 59-64.

Palmborg, C., Nordgren, A., 1993. Modelling microbial 
activity and biomass in forest soil with substrate quality measured using near infrared reflectance spectroscopy. Soil Biology and Biochemistry 25, 1713-1718.

Pandey, K.K., 1999. A study of chemical structure of soft and hardwood and wood polymers by FTIR spectroscopy. Journal of Applied Polymer Science 71, 1969-1975.

Parton, W.J., Schimel, D.C., Cole, C.V., Ojima, D.S., 1987. Analysis of factors controlling soil organic matter levels in Great Plains grasslands. Soil Science Society of America Journal 51, 1173-1179.

Pastorova, I., Botto, R.W., Arisz, P.W., Boon, J.J., 1994. Cellulose char structure: a combined analytical Py-GC-MS, FTIR and NMR study. Carbohydrate Research 262, 27-47.

Pietikäinen, J., Fritze, H., 1995. Clear-cutting and prescribed burning in coniferous forest: comparison of effects on soil fungal and total microbial biomass respiration and activity and nitrification. Soil Biology and Biochemistry 27, 101-109.

Pietikäinen, J., Hiukka, R., Fritze, H., 2000. Does short-term heating of forest humus change its properties as a substrate for microbes. Soil Biology and Biochemistry 32, 277-288.

Preston, C.M., 1996. Applications of NMR to soil organic matter analysis: history and prospects. Soil Science 161, 144 166.

Preston, C.M., Sollins, P., Sayer, B.G., 1990. Changes in organic components for fallen logs in old-growth Douglas-fir forests monitored by ${ }^{13} \mathrm{C}$ nuclear magnetic resonance spectroscopy. Canadian Journal of Forest Research 20, 13821391.

Preston, C.M., Trofymow, J.A., Niu, J., Fyfe, C.A., 1998. CPMAS ${ }^{13} \mathrm{C}$ NMR spectroscopy and chemical analysis of coarse woody debris in coastal forests of Vancouver Island. Forest Ecology and Management 111, 51-68.

Saldarriaga, J.G., West, D.C., 1986. Holocene fires in the northern Amazon basin. Quaternary Research 26, 358-366.

Saranpää, P., Nyberg, H., 1987. Lipids and sterols of Pinus sylvestris L. sapwood and heartwood. Trees Structure and Function 1, 82.

Schmidt, M.W.I., Noack, A.G., 2000. Black carbon in soils and sediments: analysis, distribution, implications and current challenges. Global Biogeochemical Cycles 14, 777-793.

Schmidt, M.W.I., Skjemstad, J.O., Gehrt, E., Kögel-Knaber, I., 1999. Charred organic carbon in German chernozemic soils. European Journal of Soil Science 50, 351-365.

Scott, C.D., Standberg, G.W., Lewis, S.N., 1986. Microbial solubilization of coal. Biotechnology Progress 2, 131-139.

Sekiguchi, Y., Frye, J.S., Shafizadeh, F., 1983. Structure and formation of cellulosic chars. Journal of Applied Polymer Science 28, 3513-3525.

Shafizadeh, F. (Ed.), 1984. The Chemistry of Solid Wood. American Chemical Society, Washington, DC.

Shindo, H., 1991. Elementary composition, humus composition, and decomposition in soil of charred grassland plants. Soil Science and Plant Nutrition 37, 651-657.

Skjemstad, J.O., Clarke, P., Taylor, J.A., Oades, J.M., McClure, S.G., 1996. The chemistry and nature of protected carbon in soil. Australian Journal of Soil Research 34, 251-271.

Skjemstad, J.O., Taylor, J.A., Janik, L.J., Marvanek, S.P., 1999a. Soil organic carbon dynamics under long-term sugarcane monoculture. Australian Journal of Soil Research 37, 151-164.

Skjemstad, J.O., Taylor, J.A., Smernik, R.J., 1999b. Estimation of charcoal (char) in soils. Communications in Soil Science and Plant Analysis 30, 2283-2298.

Smernik, R.J., Baldock, J.A., Oades, J.M., Whittaker, A.K., 2002a. Determination of $T_{1} \rho H$ relaxation rates in charred and uncharred wood and consequences for NMR quantitation. Solid State Nuclear Magnetic Resonance (in press).

Smernik, R.J., Baldock, J.A., Oades, J.M., 2002b. Impact of protonation on ${ }^{13} \mathrm{C}$ CPMAS NMR quantitation of charred and uncharred wood. Solid State Nuclear Magnetic Resonance (in press).

Smernik, R.J., Oades, J.M., 1999. Effect of added paramagnetic ions on the ${ }^{13} \mathrm{C} \mathrm{CP} / \mathrm{MAS}$ NMR spectrum of a de-ashed soil. Geoderma 89, 219-248.

Smernik, R.J., Oades, J.M., 2000a. The use of spin counting for determining quantitation in solid state ${ }^{13} \mathrm{C}$ NMR spectra of natural organic matter. 2. HF-treated soil fractions. Geoderma 96, 159-171.

Smernik, R.J., Oades, J.M., 2000b. The use of spin counting for determining quantitation in solid state ${ }^{13} \mathrm{C}$ NMR spectra of natural organic matter. 1. Model systems and the effects of paramagnetic impurities. Geoderma 96, 101-129.

Smernik, R.J., Oades, J.M., 2000c. Effect of paramagnetic cations on solid state ${ }^{13} \mathrm{C}$ nuclear magnetic resonance spectra of natural organic materials. Communications in Soil Science and Plant Analysis 31, 3011-3026.

Smernik, R.J., Oades, J.M., 2001. Background signal in solid state ${ }^{13} \mathrm{C}$ NMR spectra of soil organic matter (SOM) quantification and minimization. Solid State Nuclear Magnetic Resonance 20, 74-84.

Smernik, R.J., Skjemstad, J.O., Oades, J.M., 2000. Virtual fractionation of charcoal from soil organic matter using solid-state ${ }^{13} \mathrm{C}$ NMR spectral editing. Australian Journal of Soil Research 38, 665-683.

StatSoft, 2001. STATISTICA for Windows (Computer Program Manual). StatSoft, Inc., Tulsa, OK.

Torn, M.S., Trumbore, S.E., Chadwick, O.A., Vitousek, P.M., Hendricks, D.M., 1997. Mineral control of soil organic carbon storage and turnover. Nature 389, 170-173.

van der Marel, H.W., Beutelspacher, H., 1976. Atlas of Infrared Spectroscopy of Clay Minerals and their Admixtures. Elsevier Scientific Publishing Company, New York.

van Krevelen, D.W., 1950. Graphical-statistical method for the study of structure and reaction processes of coal. Fuel 29, 269-284.

Van, Wagner, C.E., 1980. Fire behaviour in northern conifer forests and shrublands. In: Wein, R.W., MacLean, D.A. (Eds.), Fire in Northern Circumpolar Ecosystems. Academic Press, New York, pp. 45-80.

VanderHart, D.L., Attala, R.H., 1984. Studies of microstructure in native celluloses using solid-state ${ }^{13} \mathrm{C}$ NMR. Macromolecules 17, 1465-1472.

Wilson, M.A., 1987. N.M.R. Techniques and Applications in Geochemistry and Soil Chemistry. Pergamon Press, Oxford. 